\title{
Increasing livestock wastewater application in alternate-furrow irrigation reduces nitrification gene abundance but not nitrification rate in rhizosphere
}

\author{
Yuan Liu ${ }^{1}$ - Andrew L. Neal ${ }^{2}$ - Xiaoxian Zhang ${ }^{2}$ - Erping Cui ${ }^{1} \cdot$ Feng Gao ${ }^{1} \cdot$ Xiangyang Fan ${ }^{1} \cdot$ Chao Hu $^{1}$. \\ Zhongyang Li ${ }^{1}$ (D)
}

Received: 15 November 2018 / Revised: 31 March 2019 / Accepted: 2 April 2019 / Published online: 18 April 2019

(C) The Author(s) 2019

\begin{abstract}
In water-scarce regions, alternate-furrow irrigation (AFI) - alternately wetting half of the plant roots - has proven to be an effective water-saving approach without compromising yield. However, the extent to which AFI with wastewater affects N cycling genes remains poorly studied. We aimed to investigate changes in main $\mathrm{N}$ transformation processes, bacterial and fungal community composition, as well as relative abundance of $\mathrm{N}$ cycle-associated genes in soil receiving AFI with swine wastewater. The experimental plan included three irrigation rates, irrigating pepper plants with $50 \%, 65 \%$, and $80 \%$ of the amount of water required under conventional furrow irrigation to prevent the crop suffering water stress. Each treatment had a groundwater irrigation control. We measured edaphic factors, microbial community composition, and relative abundance of genes in rhizosphere and bulk soils. Altering water use in AFI did not exert a significant effect on bacterial and fungal communities. By increasing the irrigation rate of wastewater, relative abundances of $n i f H$, bacterial and archaeal amoA and nos $Z$ genes decreased, whereas those of nirK and nirS genes increased in the rhizosphere soil; nitrification rate did not decrease and the denitrification rate remained unchanged in both rhizosphere and bulk soil, implying that appropriate increase of wastewater use by AFI can improve $\mathrm{N}$ use efficiency.
\end{abstract}

Keywords Livestock wastewater $\cdot$ Alternate-furrow irrigation $\cdot$ Irrigation amount $\cdot$ Nitrogen transformation genes $\cdot$ Water quality

\section{Introduction}

Recycling nutrient-rich livestock wastewaters and reusing them for irrigation (Cai et al. 2013) is an attractive approach to relieve water-shortage pressure, capture $\mathrm{N}$ and other nutrients in plant biomass and soil, and dispose of wastes in a managed manner. Irrigation with nutrient-rich wastewater is likely to alter $\mathrm{N}$ transformations in soils including nitrification, denitrification, $\mathrm{N}_{2}$-fixation, anaerobic ammonium oxidation (anammox), and complete ammonia oxidation (commamox)

Electronic supplementary material The online version of this article (https://doi.org/10.1007/s00374-019-01361-y) contains supplementary material, which is available to authorized users.

Zhongyang Li

lizhongyang1980@163.com

1 Farmland Irrigation Research Institute, Chinese Academy of Agricultural Sciences, Xinxiang 453002, China

2 Department of Sustainable Agriculture Sciences, Rothamsted Research, Harpenden, Hertfordshire AL5 2JQ, UK to $\mathrm{NO}_{3}{ }^{-}-\mathrm{N}$. During nitrification, $\mathrm{NH}_{4}{ }^{+}$is oxidized progressively to $\mathrm{NO}_{2}{ }^{-}$and then to $\mathrm{NO}_{3}{ }^{-}$. Ammonia oxidation is a rate-limiting process in nitrification under aerobic condition, mediated by both ammonia-oxidizing archaea (AOA) and ammonia-oxidizing bacteria (AOB) (Könneke et al. 2005). The sequential reduction of $\mathrm{NO}_{3}{ }^{-}$and $\mathrm{NO}_{2}{ }^{-}$to nitric oxide (NO), or nitrous oxide $\left(\mathrm{N}_{2} \mathrm{O}\right)$ or dinitrogen gas $\left(\mathrm{N}_{2}\right)$ in denitrification are anaerobic microbial processes, driven by denitrifying microorganisms that involve nitrate reductase (encoded by narG and napA), nitrite reductase (nirK and nir $S$ ), nitric oxide reductase (nor $B$ and nor $C$ ), and nitrous oxide reductase (nosZ) ( $\mathrm{Li}$ et al. 2018).

$\mathrm{N}_{2} \mathrm{O}$ is a greenhouse gas 300 times more potent than $\mathrm{CO}_{2}$ and it is also responsible for ozone depletion (Mosier et al. 1998). Reducing its emission from arable soil is thus imperative (Ravishankara et al. 2009), especially since agriculture in China remains a net source of greenhouse gases (Gao et al. 2018). $\mathrm{N}_{2} \mathrm{O}$ emission is modulated by functional genes involved in nitrite reduction, such as nirS and nirK, and nosZ, which encode nitrous oxide reductase (Zehr and Kudela 2011; Hu et al. 2015). 
The abundance and activity of nitrifying and denitrifying microorganisms in soil is influenced by organic matter (OM), $\mathrm{pH}$, total $\mathrm{N}(\mathrm{TN})$, organic $\mathrm{C}$, temperature, $\mathrm{NH}_{4}{ }^{+}$, and $\mathrm{NO}_{3}{ }^{-}$, among other factors (Henry et al. 2006; Dong et al. 2009; Li et al. 2018; Shan et al. 2018). Growth of AOB depends on the availability of $\mathrm{NH}_{4}{ }^{+}$(Martens-Habbena et al. 2009). A study on $\mathrm{N}$ dynamics in plant-soil systems in a riparian zone showed that there were significant negative correlations between abundance of nirK, nirS, nos Z genes, and soil electrical conductivity (EC), while abundance of nifH was negatively associated with soil bulk density as opposed to abundance of archaeal amoA; it was also found that increasing soil water content led to an increase in nif $H$ abundance but decrease in archaeal amoA abundance (de Sosa et al. 2018). Increasing the availability of $\mathrm{NO}_{3}{ }^{-}$and labile $\mathrm{C}$ enhances denitrification (Weier et al. 1993), high $\mathrm{NO}_{3}{ }^{-}$concentration inhibits $\mathrm{N}_{2} \mathrm{O}$ reductase activity (Qin et al. 2017), and low $\mathrm{C} / \mathrm{N}$ ratio or high total $\mathrm{N}$ favors bacteria harboring amoA genes (Nugroho et al. 2006; Dong and Reddy 2012). Tillage induced physicochemical stratification impacts abundance of $\mathrm{N}$ cycling microbial communities and net $\mathrm{N}_{2} \mathrm{O}$ emissions within the soil profile according to $\mathrm{N}$ or $\mathrm{C}$ compounds added during fertilization with an inorganic fertilizer (calcium ammonium nitrate) or two organic fertilizers (liquid dairy slurry and dairy manure compost) (Krauss et al. 2017).

Apart from these edaphic factors, irrigation methods and frequency may also influence the abundance and activity of microorganisms and their associated $\mathrm{N}$ transformation genes directly through changes in water and oxygen distributions, or indirectly through changes in diffusion and transport of substrates, pH and temperature, etc. (Zhou et al. 2011; Wertz et al. 2013; Yin et al. 2015; Hou et al. 2016; Owens et al. 2016; Han et al. 2017; Yang et al. 2018). The effects of irrigation amount on N-related microbial activity and gene abundance are not established (Berger et al. 2013; Zhang et al. 2016; Azziz et al. 2017), suggesting that the effects of irrigation on microbial community and $\mathrm{N}$-transformation genes are poorly understood.

In arid and semi-arid regions, alternate-furrow irrigation (AFI) has been developed as an efficient water-saving irrigation method (Graterol et al. 1993; Kang et al. 2000a, 2000b). AFI irrigates each of two adjacent furrows alternately, and by keeping roots in the dry furrow for a prolonged period, stimulates synthesis of abscisic acid (ABA) in attempts to reduce leaf stomatal conductance and ultimately plant transpiration. Compared to conventional furrow irrigation (CFI), AFI has the potential to reduce $\mathrm{N}_{2} \mathrm{O}$ emissions (Han et al. 2014), but its effect upon the abundance of $\mathrm{N}$ cycle genes in soil is poorly understood.

Given the increase in use of AFI and wastewater in irrigation, we investigated the response of abundance of $\mathrm{N}$-cycle genes and main $\mathrm{N}$ transformation processes in a pepper field irrigated with different amounts of swine wastewater under
AFI. For each treatment, there was a groundwater irrigation control. We hypothesized that (1) wetting-drying cycles associated with AFI exert different effects on $\mathrm{N}$ transformation processes and the abundance of associated $\mathrm{N}$-cycle genes in soil from CFI, and (2) the irrigation amounts with AFI change $\mathrm{N}$ transformation processes and the abundance of associated $\mathrm{N}$-cycle genes in soil synchronously. In all treatments and controls, we measured the main $\mathrm{N}$ transformation activities, distribution of $\mathrm{N}$ cycling genes, and the composition of bacterial and fungal communities, and analyzed their association with edaphic factors. This will fill the knowledge gap of how AFI with wastewater influences $\mathrm{N}$ transformation activities and the related genes, and provide a reference of $\mathrm{N}$ management for sustainable use of livestock wastewater in agricultural production in arid and semiarid regions.

\section{Materials and methods}

\section{Soil and water}

The field experiment was conducted at the Agriculture Water and Soil Environmental Field Science Research Station of Chinese Academy of Agricultural Science at Xinxiang (Henan Province, $35^{\circ} 15^{\prime} 44^{\prime \prime} \mathrm{N}, 113^{\circ} 55^{\prime} 6^{\prime \prime} \mathrm{E}$ ). All experimental plots were covered by a vinyl shield $5 \mathrm{~m}$ above the ground surface to intercept rainwater, and the soil is sandy loam classified as fluvic Cambisol. The main properties of the top $20 \mathrm{~cm}$ of soil were $\mathrm{pH} 8.5$, electrical conductivity $87.7 \mathrm{mS} \mathrm{m}^{-1}$, OM $9.0 \mathrm{~g} \mathrm{~kg}^{-1}$, total $\mathrm{N} 0.7 \mathrm{~g} \mathrm{~kg}^{-1}, \mathrm{NO}_{3}{ }^{-} \mathrm{-N}$ $136 \mathrm{mg} \mathrm{kg}^{-1}$, exchangeable $\mathrm{NH}_{4}{ }^{+}-\mathrm{N} 7.9 \mathrm{mg} \mathrm{kg}^{-1}$, available $\mathrm{K} 252 \mathrm{mg} \mathrm{kg}^{-1}$, available $\mathrm{P} 33.2 \mathrm{mg} \mathrm{kg}^{-1}$, total $\mathrm{Cu}$ $25.7 \mathrm{mg} \mathrm{kg}^{-1}$, total $\mathrm{Zn} 72.4 \mathrm{mg} \mathrm{kg}^{-1}$, total $\mathrm{Pb} 22.0 \mathrm{mg} \mathrm{kg}^{-1}$, total $\mathrm{Cd} 0.60 \mathrm{mg} \mathrm{kg}^{-1}$, available $\mathrm{Cu} 1.5 \mathrm{mg} \mathrm{kg}^{-1}$, available $\mathrm{Zn}$ $1.8 \mathrm{mg} \mathrm{kg}^{-1}$, available $\mathrm{Pb} 1.9 \mathrm{mg} \mathrm{kg}{ }^{-1}$, and available $\mathrm{Cd}$ $0.20 \mathrm{mg} \mathrm{kg}^{-1}$.

The groundwater used in the experiment was pumped from a shallow aquifer at the experimental site, and wastewater was taken from a fermentation tank at a near-by hoggery producing approximately 40,000 tons of wastewater annually. The properties of the waters are shown in Table 1.

\section{The plant and the field experiment}

The plant used in the experiment was pepper (Capsicum annuит L., Fulong F1). The seedling medium was a mixture of perlite and vermiculite at 1:1 ratio (weight), which was packed into a seedling-nursing disk consisting of $4 \times 8$ cavities, each being $5.8 \mathrm{~cm}$ high with its internal diameter changing from $5.3 \mathrm{~cm}$ on the top to $2.7 \mathrm{~cm}$ on the bottom. All pepper seeds were sown on April 14, 2017 and were subsequently supplied with Hoagland and Amon nutrient solutions based on the protocol provided in Li et al. (2010). The field soil was 
Table 1 Properties of groundwater and wastewater used in this study

\begin{tabular}{|c|c|c|c|c|c|c|c|c|c|c|c|}
\hline & $\begin{array}{l}\mathrm{pH} \\
-\end{array}$ & $\begin{array}{l}\mathrm{EC} \\
\mathrm{mS} \mathrm{cm}{ }^{-1}\end{array}$ & $\begin{array}{l}\mathrm{COD}^{\mathrm{a}} \\
\mathrm{mg} \mathrm{L}^{-1}\end{array}$ & $\begin{array}{l}\mathrm{TDS}^{\mathrm{b}} \\
\mathrm{mg} \mathrm{L}^{-1}\end{array}$ & $\begin{array}{l}\mathrm{N} \\
\mathrm{mg} \mathrm{L}^{-1}\end{array}$ & $\begin{array}{l}\mathrm{P} \\
\mathrm{mg} \mathrm{L}^{-1}\end{array}$ & $\begin{array}{l}\mathrm{Ca} \\
\mathrm{mg} \mathrm{L}^{-1}\end{array}$ & $\begin{array}{l}\mathrm{Mg} \\
\mathrm{mg} \mathrm{L}^{-1}\end{array}$ & $\begin{array}{l}\mathrm{Fe} \\
\mathrm{mg} \mathrm{L}^{-1}\end{array}$ & $\begin{array}{l}\mathrm{Zn} \\
\mathrm{mg} \mathrm{L}\end{array}$ & $\begin{array}{l}\mathrm{Mn} \\
\mu \mathrm{g} \mathrm{L}^{-1}\end{array}$ \\
\hline Groundwater & 8.07 & 1.985 & 104 & 2251 & 0.550 & - & 55.5 & 122 & 1.07 & 0.021 & 178 \\
\hline \multirow[t]{2}{*}{ Wastewater } & 8.40 & 2.588 & 330 & 1681 & 325.6 & 16.6 & 47.6 & 38.6 & 0.88 & 0.366 & 120 \\
\hline & $\begin{array}{l}\mathrm{Pb} \\
\mu \mathrm{g} \mathrm{L}^{-1}\end{array}$ & $\begin{array}{l}\mathrm{Cd} \\
\mu \mathrm{g} \mathrm{L}^{-1}\end{array}$ & $\begin{array}{l}\mathrm{Cu} \\
\mu \mathrm{g} \mathrm{L}^{-1}\end{array}$ & $\begin{array}{l}\mathrm{Cr} \\
\mu \mathrm{g} \mathrm{L}^{-1}\end{array}$ & $\begin{array}{l}\text { As } \\
\mu g \mathrm{~L}^{-1}\end{array}$ & $\begin{array}{l}\mathrm{Hg} \\
\mu g \mathrm{~L}^{-1}\end{array}$ & $\begin{array}{l}\mathrm{NO}_{3}^{-} \\
\mathrm{mg} \mathrm{L}^{-1}\end{array}$ & $\begin{array}{l}\mathrm{PO}_{4}{ }^{3-} \\
\mathrm{mg} \mathrm{L}^{-1}\end{array}$ & $\begin{array}{l}\mathrm{SO}_{4}{ }^{2-} \\
\mathrm{mg} \mathrm{L}^{-1}\end{array}$ & $\begin{array}{l}\mathrm{K}^{+} \\
\mathrm{mg} \mathrm{L}^{-1}\end{array}$ & $\begin{array}{l}\mathrm{Na}^{+} \\
\mathrm{mg} \mathrm{L}^{-1}\end{array}$ \\
\hline Groundwater & 0.654 & 0.050 & 2.45 & 13.3 & 9.85 & 0.065 & - & - & 844 & 2.95 & 514 \\
\hline Wastewater & 1.729 & 0.107 & 73.16 & 30.0 & 2.10 & 0.178 & 2.70 & 4.94 & 319 & 212.3 & 257 \\
\hline
\end{tabular}

${ }^{\text {a }}$ Chemical oxygen demand

${ }^{\mathrm{b}}$ Total dissolved solids; the content of N, P, Ca, Mg, Fe, $\mathrm{Zn}, \mathrm{Mn}, \mathrm{Cu}, \mathrm{Pb}, \mathrm{Cd}, \mathrm{Cr}$, As, Hg refers to the total content

initially amended with a base fertilizer consisting of $180 \mathrm{~kg}$ urea ha ${ }^{-1}\left(84 \mathrm{~kg} \mathrm{~N} \mathrm{ha}^{-1}\right), 450 \mathrm{~kg} \mathrm{Ca}\left(\mathrm{H}_{2} \mathrm{PO}_{4}\right)_{2} \cdot \mathrm{H}_{2} \mathrm{O} \mathrm{ha}^{-1}$, and $240 \mathrm{~kg} \mathrm{KCl} \mathrm{ha}{ }^{-1}$. One month after seed germination, healthy seedlings were transplanted to the field. Seedlings were transplanted into rows spaced $50 \mathrm{~cm}$ apart and planted at $50 \mathrm{~cm}$ intervals along each row. Each plot was $2 \times 8 \mathrm{~m}$, formed of three rows separated by four $30 \mathrm{~cm}$-deep furrows. There was a $50 \mathrm{~cm}$ gap between adjacent plots to avoid water flowing from one plot into another. Prior to wastewater irrigation, each plot was irrigated with groundwater at $250 \mathrm{~m}^{3} \mathrm{ha}^{-1}$ via CFI every 7 days until 19 June to establish and maintain healthy plant growth.

The soil was top-dressed with $90 \mathrm{~kg}$ of urea ha ${ }^{-1}$ (42 $\mathrm{kg} \mathrm{N} \mathrm{ha}^{-1}$ ) on July 21, August 12, and September 3. The total urea applied during the experiment was $450 \mathrm{~kg} \mathrm{ha}^{-1}\left(210 \mathrm{~kg} \mathrm{~N} \mathrm{ha}^{-1}\right)$. In wastewater treatments, we diluted the wastewater with groundwater at 1:1 volumetric ratio prior to irrigation. There were eight treatments: irrigating with groundwater at $250 \mathrm{~m}^{3} \mathrm{ha}^{-1}$ approximately every 10 days via CFI (GC100), AFI with groundwater using $50 \%$ of the water used in GC100 (GA50), AFI with groundwater using $65 \%$ of the water used in GC100 (GA65), AFI with groundwater using $80 \%$ of the water used in GC100 (GA80), CFI with wastewater using the same amount of the water in GC100 (WC100), AFI with wastewater using 50\% of the water used in WC100 (WA50), AFI with wastewater using $65 \%$ of the water used inWC100 (WA65), and AFI with wastewater using $80 \%$ of the water used in WC100 (WA80).

Each treatment had three replicate plots arranged in a completely randomized design. Plots were irrigated on June 19, June 28, July 9, July 21, August 1, and August 12, at approximately the same time. Following Kang et al. (2000b), both adjacent furrows were watered under CFI, but only one furrow was watered under AFI with the same water amount of each CFI furrow: the total water amount of AFI was $50 \%$ of CFI. Here, we refer to the water amount in CFI as $100 \%$, thus $50 \%$ in AFI. These two treatments with the only difference in irrigated furrows but not the difference in irrigation amount in each furrow were used to examine the effects of
AFI. AFI under 50\%, 65\%, and $80 \%$ rates were used to study the impact of irrigation amount on $\mathrm{N}$ transformation activities as well as distribution and abundance of $\mathrm{N}$ cycling genes.

Prior to harvest on 9 October, all plots were irrigated with groundwater at $250 \mathrm{~m}^{3} \mathrm{ha}^{-1}$ via CFI every 7 days starting from 23 August. Details of the irrigation schedule are listed in Table S1. At harvest, roots were sampled to a depth of 0 $20 \mathrm{~cm}$. Soil shaken off the roots was termed bulk soil (BS) and soil adhering to roots was termed rhizosphere (RS). In each plot, soil collected from five randomly selected plant roots was mixed. Sub-samples were stored at $-80{ }^{\circ} \mathrm{C}$ for extraction of nucleic acids and determination of nitrification and nitrogen fixation rates (see description in the Supplementary Information), and the rest for measurement of soil chemical properties and denitrification rate (see description in the Supplementary Information). Thawing a frozen-stored sample might result in altered rates from those in the field when the sample was taken, but the reported research in the literature concerning this is not conclusive, with some showing a small change while others finding no observable alternation (Stenberg et al. 1998). Nonetheless, all samples in our work were stored and measured following the same protocol and the methodological effects were thus consistent, as pointed out by Rubin et al. (2013) that methodological consistency is key to ensure accurate characterization and comparison of soil microbial community. As such, the results comparison between different treatments is reasonable. The total $\mathrm{N}$ of plant roots, stems, leaves, and fruits were analyzed on a flow analyzer (AutoAnalyzer 3, Bran Luebbe, Germany) after digestion with concentrated sulfuric acid. $\mathrm{N}$ use efficiency of plants was calculated by Eq. (1) (Yang et al. 2017).

$\mathrm{N}$ use efficiency $(\%)=$ plant $\mathrm{N} /$ added $\mathrm{N} \times 100$

where "plant $\mathrm{N}$ " was the sum of $\mathrm{N}$ from all tissues in each plot, and "added $\mathrm{N}$ " was the sum of $\mathrm{N}$ from fertilizer and irrigated water in each plot. 


\section{DNA extraction}

A FastDNA SPIN Kit for Soil (MP Biomedicals, CA) was used to extract total DNA from about $0.5 \mathrm{~g}$ of each soil sample according to the instruction manual, and three replicates were extracted for each sample (Vestergaard et al. 2017). We used spectrophotometric analysis (NanoDrop ND-2000c, Thermo Fisher Scientific, Waltham, MA) and $1.5 \%$ agarose gel electrophoresis to determine the concentration and quality of the extracted DNA.

\section{MiSeq pyrosequencing}

PCR amplification of the bacterial 16S rRNA gene V3-V4 variable region was performed using the forward primer $5^{\prime}$ ACTCCTACGGGAGGCAGCAG-3' (338F) and the reverse primer 5'-GGACTACHVGGGTWTCTAAT-3' (806R) (Xu et al. 2016). The primers ITS3 (5'-GCATCGATGAAGAA CGCAGC-3') (Leaw et al. 2006) and ITS4 (5'-TCCT CCGCTTATTGATATGC-3') (Siddique and Unterseher 2016) were used to amplify the fungal ITS regions. The reaction mixture and the thermal profile of the PCR amplifications were based on Huang et al. (2016). After the PCR products were purified, they were adjusted to equal quantities, and paired-end $2 \times 300$ base pair (bp) sequencing was performed on an Illumina MiSeq sequencing platform by Shanghai Personal Biotechnology Co., Ltd. (Shanghai, China).

Sequences were examined for quality using the default arguments in the split_libraries python script apart from increasing primer mismatch from 0 to 2 , and were then assigned to each sample based on unique 10-bp barcodes. After removing barcode and primer sequences, the remaining sequences were clustered into operational taxonomic units (OTUs) at a level of 97\% sequence similarity (Schöler et al. 2017) and annotated using BLAST searches against the Greengenes (Release 13.8, http://greengenes.secondgenome.com/, bacteria) and Unite (Release 5.0, http://unite.ut.ee/index.php, fungi) databases using the Quantitative Insights into Microbial Ecology (QIIME) software package version 1.8.0 (Caporaso et al. 2010).

\section{Relative quantification of genes}

The N-cycle related genes we investigated were involved in $\mathrm{N}_{2}$ fixation (nifH), ammonia oxidation (archaeal amoA and bacterial $a m o A$ ), nitrite reduction (nirK and nirS), and nitrous oxide reduction (nosZ). Genes were amplified and quantified using the quantitative polymerase chain reaction (qPCR) and the SYBR Green approach at Shanghai Personal Biotechnology Co., Ltd. (Shanghai, China). All qPCR reactions were repeated three times. The primer description can be found in Table S2. All qPCR reactions were performed using the CFX-96 touch real-time PCR detection system (Bio-Rad,
USA). Cycle conditions were $95{ }^{\circ} \mathrm{C}$ for $5 \mathrm{~min}$, followed by 45 cycles of $95^{\circ} \mathrm{C}$ for $15 \mathrm{~s}, 60^{\circ} \mathrm{C}$ for $30 \mathrm{~s}$, and $72{ }^{\circ} \mathrm{C}$ for $30 \mathrm{~s}$. A threshold cycle $\left(C_{\mathrm{t}}\right)$ of 36 was used as the detection limit (Malvick and Impullitti 2007). Generally, the technical triplicates were tested during separate testing occasions (plate and day of testing) as a method of quality control. The $2^{-\Delta \Delta C t}$ method of comparison (Livak and Schmittgen 2001; Zhu et al. 2013) was used to compare relative gene abundance between samples:

$$
\begin{aligned}
& \Delta C_{\mathrm{t}}=C_{\mathrm{t},(\mathrm{N} \text { cycling gene })}-C_{\mathrm{t},(16 \mathrm{~S})} \\
& \Delta \Delta C_{\mathrm{t}}=\Delta C_{\mathrm{t},(\text { Target })}-\Delta C_{\mathrm{t},(\text { Ref })}
\end{aligned}
$$

where $C_{\mathrm{t}}$ is the threshold cycle, $\mathrm{N}$ cycling gene is one of the $\mathrm{N}$ cycling gene assays, $16 \mathrm{~S}$ is the $16 \mathrm{~S}$ rRNA gene assay, the subscripts Target and Ref refer to experimental sample and reference sample respectively. To identify changes in Ncycle associated gene abundance between soil samples taken from all treatments, the soil before cultivation and fertilization was used as the reference sample in all calculations.

\section{Statistical analysis}

We compared the gene abundance and environmental parameters statistically using SPSS 16.0 for Windows (SPSS Inc., Chicago, IL, USA). One-factor analysis of variance (ANOVA) was used to test differences between treatments, and Duncan's multiple range test was used to conduct posthoc pairwise comparisons of treatment-means. A probability of $p<0.05$ was deemed to be significant. Two-factor ANOVA of gene abundance, nitrification rate, denitrification rate, and $\mathrm{N}$ use efficiency was conducted to test the effect of water source and irrigation amount.

OTU data was analyzed using MicrobiomeAnalyst (Dhariwal et al. 2017), using a minimum mean abundance cut-off of 20 across all treatments. A low variance filter was also used to remove OTUs associated with the lowest $10 \%$ of coefficients of variance, determined using the inter-quantile range. Cumulative sum scaling (CSS) was used for gene abundance data (Weiss et al. 2017). Principal coordinate analysis (PCoA) of soil bacterial and fungal assemblages, assessed at the OTU-level, was performed using weighted UniFrac distance (Lozupone et al. 2011). The significant OTU divergence between different soils was tested using permutation multivariate analysis of variance (PERMANOVA) based again on weighted UniFrac phylogenetic distance. Whenever detecting a significant divergence between communities, we tested it for homogeneity of multivariate dispersion between the groups using PERMDISP (Anderson and Walsh 2013). Where no significant difference in multivariate dispersion was detected, the significant difference in OTU assemblages was attributed to the imposed treatment. We used the DESeq2 algorithm (Love et al. 2014) to test 
for OTUs associated with significantly different abundance in response to the significant factors.

The PCoA was used to assess differences between $\mathrm{N}$ cycling gene abundance based on the Euclidean distance in PAST 3.20, which, along with the two-factor PERMANOVA with 9999 permutations conducted in PAST, was used to evaluate the divergence of genes between different treatments. We employed redundancy analysis (RDA) to assess the association between gene abundance and environmental factors using CANOCO 5 (ter Braak 1989), where a significant treatment effect was identified. For the RDA model, statistical predictors of gene abundance were identified from the summarized effects of environmental variables. All environmental variables were transformed to $z$-scores prior to analysis, and statistical significance of the resulting RDA model was assessed based upon 999 permutations.

\section{Results}

\section{Change in soil chemical properties}

The changes in soil chemical properties influenced by irrigation are given in Table 2. Soil $\mathrm{NO}_{3}{ }^{-}-\mathrm{N}$ contents under AFI using wastewater were lower than CFI with the significant difference at $80 \%$ rate in bulk soils. For exchangeable $\mathrm{NH}_{4}{ }^{+}-$ $\mathrm{N}$ in soil, AFI at $50 \%$ and $65 \%$ rates using groundwater resulted in higher content than CFI in rhizosphere and bulk soils, and AFI at $65 \%$ and $80 \%$ rates using wastewater in both soil compartments and at $50 \%$ rate using wastewater in bulk soils, though not significantly. Soil $\mathrm{pH}$ under groundwater irrigation was higher than under wastewater irrigation, as opposed to the content of OM, TN, and $\mathrm{NO}_{3}{ }^{-}-\mathrm{N}$ as well as $\mathrm{C} / \mathrm{N}$ ratio. In all treatments, $\mathrm{EC}$ and $\mathrm{NO}_{3}{ }^{-}-\mathrm{N}$ in bulk soil were higher than in rhizosphere, in contrast to $\mathrm{OM}$ and exchangeable $\mathrm{NH}_{4}{ }^{+}-\mathrm{N}$. There were no significant differences in soil chemical properties between the three AFI treatments.

\section{$\mathrm{N}$ transformation activities}

The input and uptake of $\mathrm{N}$ and plant $\mathrm{N}$ use efficiency in different treatments are listed in Table S3. Total N input was higher in wastewater treatments than groundwater treatments, but $\mathrm{N}$ use efficiency was significantly lower in wastewater treatments. Water source, but not irrigation amount, had a significant influence upon $\mathrm{N}$ use efficiency (Table S4). There were no significant differences in $\mathrm{N}$ use efficiency between the wastewater irrigation rates. AFI significantly increased $\mathrm{N}$ use efficiency in groundwater treatments compared to CFI, and the efficiency was increased at higher rates of AFI, though not significantly. There were no significant differences in N-uptake by plants under three rates of AFI regardless of water sources, but N-uptake by plants in CFI was significantly lower than $80 \%$ rate of AFI under groundwater irrigation,

Table 2 The chemical properties in soil of different treatments

\begin{tabular}{|c|c|c|c|c|c|c|c|c|}
\hline Treatment & $\begin{array}{l}\text { Soil } \\
\text { compartment }\end{array}$ & $\mathrm{pH}$ & $\begin{array}{l}\mathrm{EC} \\
\left(\mathrm{mS} \mathrm{m}^{-1}\right)\end{array}$ & $\begin{array}{l}\text { Organic matter } \\
\left(\mathrm{g} \mathrm{kg}^{-1}\right)\end{array}$ & Total $\mathrm{N}\left(\mathrm{g} \mathrm{kg}^{-1}\right)$ & $\mathrm{C} / \mathrm{N}$ & $\begin{array}{l}\mathrm{NO}_{3}{ }^{-}-\mathrm{N} \\
\left(\mathrm{mg} \mathrm{kg}^{-1}\right)\end{array}$ & $\begin{array}{l}\text { Exchangeable } \\
\mathrm{NH}_{4}^{+}-\mathrm{N} \\
\left(\mathrm{mg} \mathrm{kg}^{-1}\right)\end{array}$ \\
\hline GC100 & RS & $8.83 \mathrm{a}$ & $110.55 \mathrm{~cd}$ & $10.90 \mathrm{ab}$ & $0.69 \mathrm{~b}$ & $6.32 \mathrm{a}$ & $75.00 \mathrm{de}$ & $7.00 \mathrm{ab}$ \\
\hline GA50 & RS & $8.77 \mathrm{ab}$ & $103.45 \mathrm{~d}$ & 16.36ab & $0.84 \mathrm{ab}$ & $9.49 \mathrm{a}$ & $68.50 \mathrm{e}$ & $11.56 \mathrm{a}$ \\
\hline GA65 & RS & $8.65 \mathrm{abcd}$ & $108.80 \mathrm{~cd}$ & $11.37 \mathrm{ab}$ & $0.67 b$ & $6.59 \mathrm{a}$ & $96.50 \mathrm{cde}$ & $8.72 \mathrm{ab}$ \\
\hline GA80 & RS & 8.61abcde & $119.75 \mathrm{bcd}$ & $12.22 \mathrm{ab}$ & $0.77 \mathrm{ab}$ & $7.09 \mathrm{a}$ & $124.50 \mathrm{bcde}$ & $3.28 \mathrm{~b}$ \\
\hline WC100 & RS & $8.50 \mathrm{cde}$ & $123.65 \mathrm{abcd}$ & $16.48 \mathrm{ab}$ & $0.72 b$ & $9.56 \mathrm{a}$ & $146.90 \mathrm{abc}$ & $6.83 \mathrm{ab}$ \\
\hline WA50 & RS & $8.48 \mathrm{de}$ & $125.00 \mathrm{abcd}$ & $17.48 \mathrm{a}$ & $0.83 \mathrm{ab}$ & $10.14 \mathrm{a}$ & $144.00 \mathrm{abc}$ & $6.50 \mathrm{ab}$ \\
\hline WA65 & RS & $8.53 \mathrm{bcde}$ & $122.05 \mathrm{abcd}$ & $13.80 \mathrm{ab}$ & $0.76 \mathrm{~b}$ & $8.01 \mathrm{a}$ & 135.06abcd & $8.61 \mathrm{ab}$ \\
\hline WA80 & RS & $8.48 \mathrm{de}$ & $125.25 \mathrm{abcd}$ & $16.15 \mathrm{ab}$ & $1.08 \mathrm{a}$ & $9.37 \mathrm{a}$ & $142.00 \mathrm{abc}$ & $10.72 \mathrm{a}$ \\
\hline GC100 & BS & $8.74 a b c$ & $142.75 \mathrm{abc}$ & $8.50 \mathrm{~b}$ & $0.66 \mathrm{~b}$ & $4.93 \mathrm{a}$ & $114.00 \mathrm{cde}$ & $5.72 \mathrm{ab}$ \\
\hline GA50 & BS & $8.65 \mathrm{abcd}$ & $144.85 \mathrm{abc}$ & $9.23 \mathrm{~b}$ & $0.73 b$ & $5.35 \mathrm{a}$ & $134.00 \mathrm{abcd}$ & $7.39 \mathrm{ab}$ \\
\hline GA65 & BS & $8.50 \mathrm{cde}$ & $149.65 \mathrm{ab}$ & $9.33 \mathrm{ab}$ & $0.64 \mathrm{~b}$ & $5.41 \mathrm{a}$ & $145.00 \mathrm{abc}$ & $8.44 a b$ \\
\hline GA80 & BS & $8.56 \mathrm{bcde}$ & $130.45 \mathrm{abcd}$ & $10.72 \mathrm{ab}$ & $0.63 b$ & $6.22 \mathrm{a}$ & $139.50 \mathrm{abc}$ & $5.44 \mathrm{ab}$ \\
\hline WC100 & BS & $8.39 \mathrm{e}$ & $159.00 \mathrm{a}$ & $9.76 \mathrm{ab}$ & $0.58 \mathrm{~b}$ & $5.66 \mathrm{a}$ & $195.50 \mathrm{a}$ & $5.39 \mathrm{ab}$ \\
\hline WA50 & BS & $8.45 \mathrm{de}$ & $138.85 \mathrm{abcd}$ & $13.59 \mathrm{ab}$ & $0.78 \mathrm{ab}$ & $7.88 \mathrm{a}$ & $183.00 \mathrm{ab}$ & $7.72 \mathrm{ab}$ \\
\hline WA65 & BS & $8.48 \mathrm{de}$ & $134.05 \mathrm{abcd}$ & $11.48 \mathrm{ab}$ & $0.79 \mathrm{ab}$ & $6.66 \mathrm{a}$ & $155.00 \mathrm{abc}$ & $7.83 \mathrm{ab}$ \\
\hline WA80 & BS & $8.49 \mathrm{de}$ & $120.65 \mathrm{bcd}$ & $12.42 \mathrm{ab}$ & $0.87 \mathrm{ab}$ & $7.20 \mathrm{a}$ & $129.00 \mathrm{bcde}$ & $8.39 \mathrm{ab}$ \\
\hline
\end{tabular}

$\mathrm{G}$ refers to groundwater, $\mathrm{W}$ refers to livestock wastewater, $\mathrm{C}$ refers to conventional furrow irrigation, A refers to alternate-furrow irrigation. 100, 50, 65, and 80 refer to $100 \%, 50 \%, 65 \%$, and $80 \%$ of full irrigation amount per plot, respectively. RS refers to rhizosphere, BS refers to bulk soil. Different lower case letters represent significant difference between treatments at $p<0.05$ 
simultaneously N-uptake by plants in CFI was significantly higher than $50 \%$ rate of AFI under wastewater irrigation.

The $\mathrm{NO}_{3}{ }^{-}-\mathrm{N}$ content in soil increased from 0 to $16 \mathrm{~h}$ after adding an ammonium solution and then decreased (data not shown), and hence we employed the difference of $\mathrm{NO}_{3}{ }^{-} \mathrm{N}$ content between 0 and $16 \mathrm{~h}$ to calculate nitrification rate. Nitrification rates were significantly influenced by water source, but not by irrigation rate in rhizosphere (Table S4). In bulk soil, the effects of water source and irrigation amount on nitrification rate were both not significant (Table S4). There were no significant differences in nitrification activity in groundwater-irrigated bulk soils; the nitrification activity in $80 \%$ rate of AFI was significantly higher than $50 \%$ rate in wastewater-irrigated bulk soils (Fig. 1).
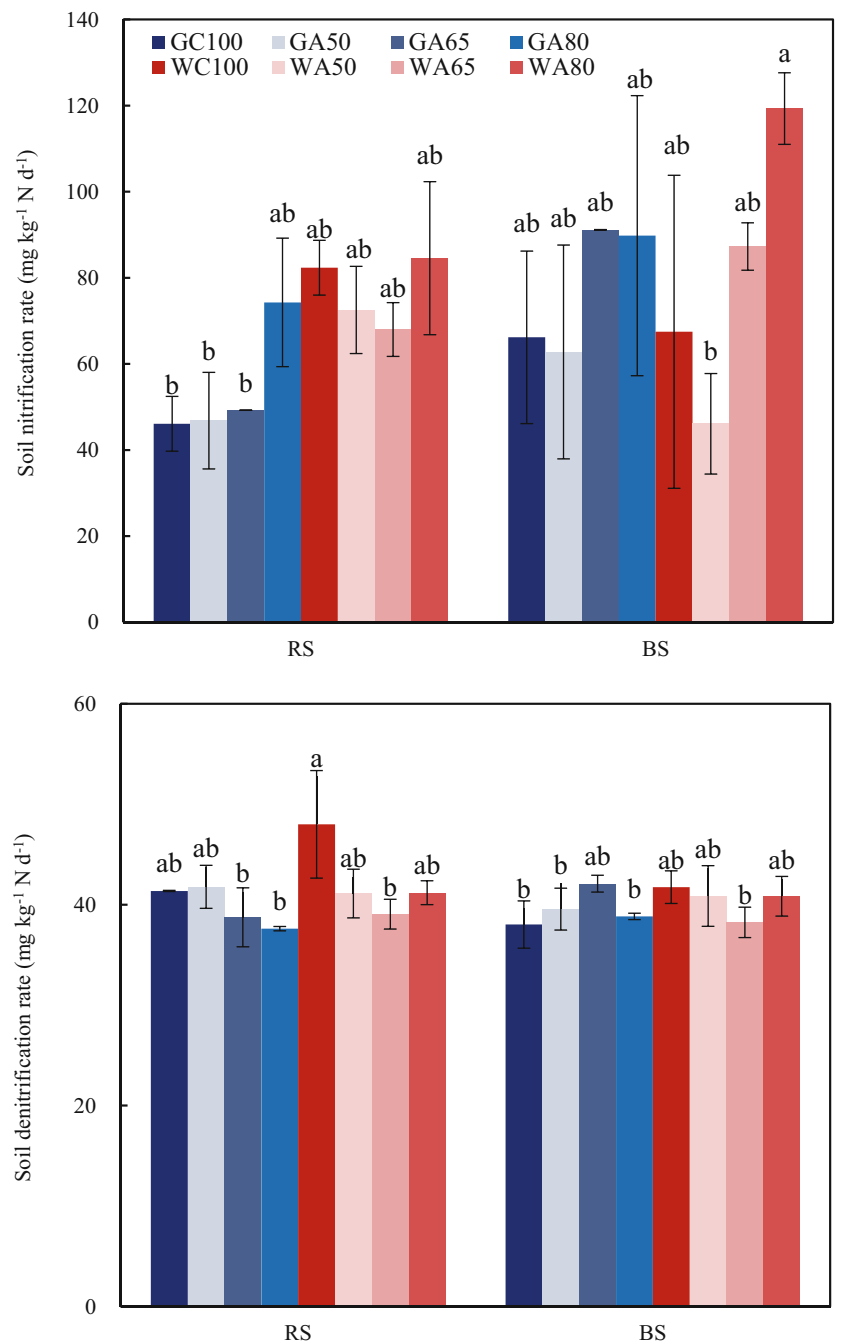

Fig. 1 The nitrification rate and denitrification rate of soil. RS refers to rhizosphere, BS refers to bulk soil, G refers to groundwater, W refers to livestock wastewater, $\mathrm{C}$ refers to conventional furrow irrigation, A refers to alternate-furrow irrigation. $100,50,65$, and 80 refer to $100 \%, 50 \%$, $65 \%$, and $80 \%$ of full irrigation amount per plot, respectively. The data are expressed as the mean \pm standard deviation. Different lower-case letters above the columns represent significant difference between treatments at $p<0.05$
The $\mathrm{NO}_{3}{ }^{-}-\mathrm{N}$ content in soil decreased over 4 days of anaerobic culture, and then stayed stable (data not shown), hence we employed the difference of $\mathrm{NO}_{3}{ }^{-}-\mathrm{N}$ content between 0 and 4 days to calculate denitrification rates. There were no significant differences of denitrification rates between soils irrigated using different water sources or rates (Table S4). In wastewater-irrigated rhizospheres, the denitrification activity in CFI was higher than that under AFI treatments and significantly higher than that at $65 \%$ AFI rate. Nitrogen fixation was not detected in any of the soils.

\section{Composition of bacterial and fungal communities}

Rarefaction curves indicated that the sequencing depth was sufficient to cover the microbial diversity (Fig. S1). We did not detect significant heterogeneity in multivariate dispersion of the OTU assemblages and so used PERMANOVA to test for differences in assemblages between rhizosphere and bulk soil under the different irrigation regimes. Both soil compartment (rhizosphere vs. bulk soil, $R^{2}=0.107, p=0.002$ ) and irrigation water source (groundwater vs. wastewater, $R^{2}=$ $0.222, p<0.001$ ) had significant effects on bacterial OTU assemblages (Fig. 2a). Variability of bacterial OTUs in wastewater-irrigated soil were reduced compared to groundwater-irrigated soil, yet different irrigation amounts did not give rise to significant difference in bacterial OTU assemblages $\left(R^{2}=0.069, p=0.318\right)$.

For fungi, significant differences in OTU assemblage were observed only between rhizosphere and bulk soils $\left(R^{2}=\right.$ $0.181, p<0.001)$. Neither water source $\left(R^{2}=0.384, p=\right.$ $0.092)$ nor irrigation rate $\left(R^{2}=0.083, p=0.166\right)$ induced significant changes in OTU assemblages.

\section{Significant difference in bacterial and fungal OTUs}

We used abundance analysis to identify OTUs whose abundance was significantly increased in response to irrigation water quality or soil compartment between irrigation treatments. For bacteria, we identified a greater number of OTUs with significantly increased abundance in groundwater-irrigated soil compared to wastewater-irrigated soil (Fig. 3). The number of OTUs whose abundance was significantly higher in the rhizosphere was similar to that in the bulk soil. However, the Phyla and Class of bacteria with significantly different abundance were distinctly different between samples (Tables S5, S6, S7, and S8). For example, OTUs which were significantly more abundant in groundwater irrigated soil were dominated by OTUs classified as either Acidobacteria (23.5\% of total OTUs) or Gemmatimonadetes (22.6\%). In contrast, those significantly more abundant in wastewater-irrigated soil were predominantly Bacteroidetes $(22.2 \%), \alpha$-Proteobacteria $(22.2 \%)$, $\gamma$-Proteobacteria (20.2\%), and Actinobacteria (14.1\%). Acidobacteria, which were the most numerous OTUs 
Fig. 2 OTU-based unconstrained principal coordinate analysis of soil bacterial (a) and fungal (b) communities using weighted UniFrac distance metrics. RS (circle) refers to rhizosphere, BS (square) refers to bulk soil, $G$ (blue color) refers to groundwater, W (red color) refers to livestock wastewater, $\mathrm{C}$ refers to conventional furrow irrigation, A refers to alternate-furrow irrigation. 50, 65,80 , and 100 refer to $50 \%$, $65 \%, 80 \%$, and $100 \%$ of full irrigation amount per plot respectively and the colors are changed from light to dark
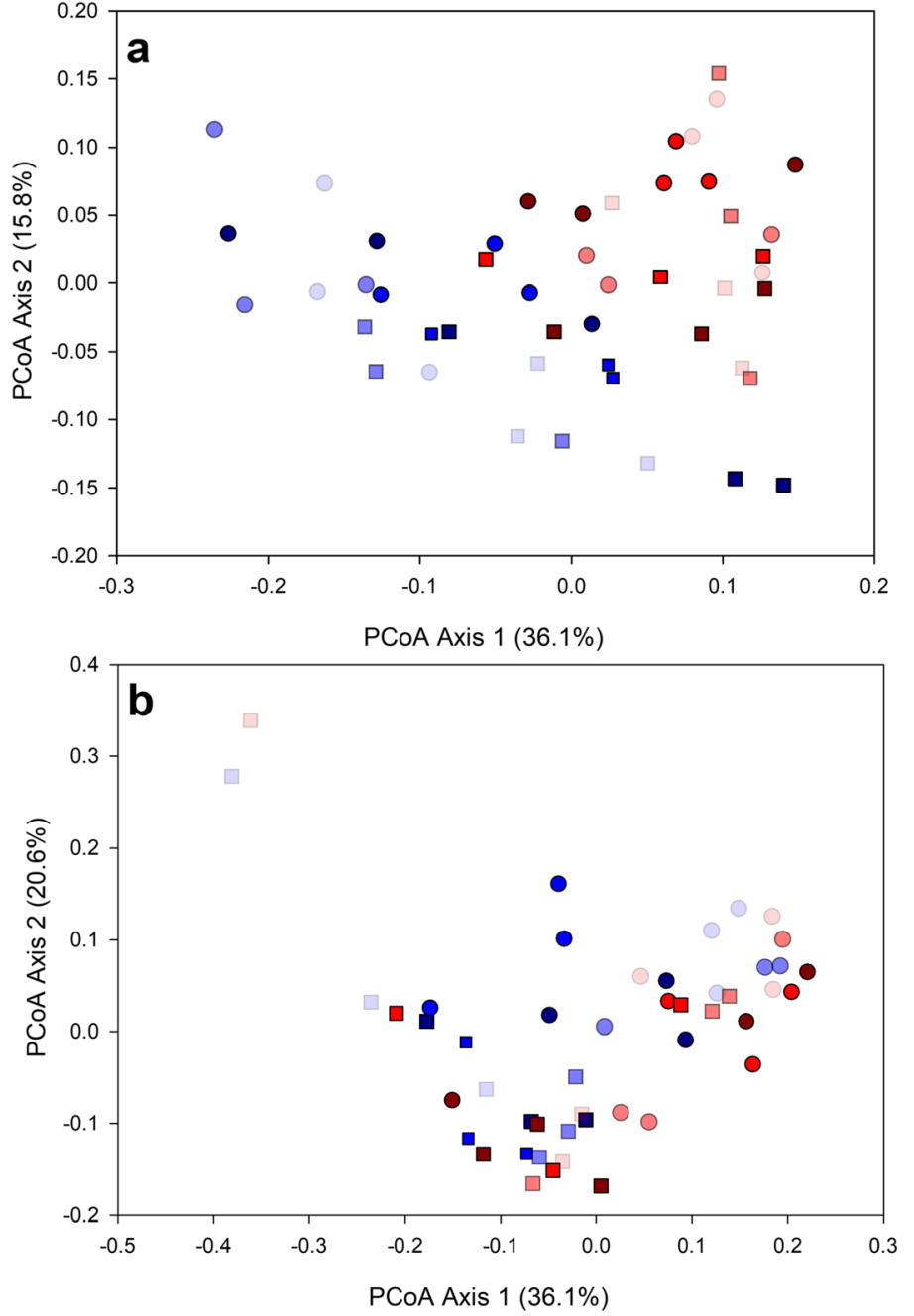

Fig. 3 Number of bacterial (a) and fungal (b) OTUs in the soil with significantly different abundances arising from different water sources or soil compartments. $G$ refers to groundwater-irrigated soil, W refers to wastewater-irrigated soil. $\mathrm{RS}$ refers to rhizosphere, BS refers to bulk soil

a

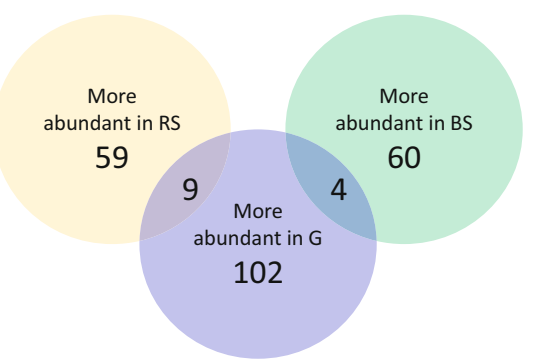

b

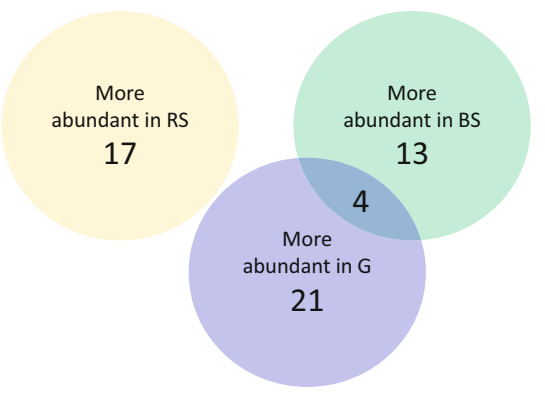

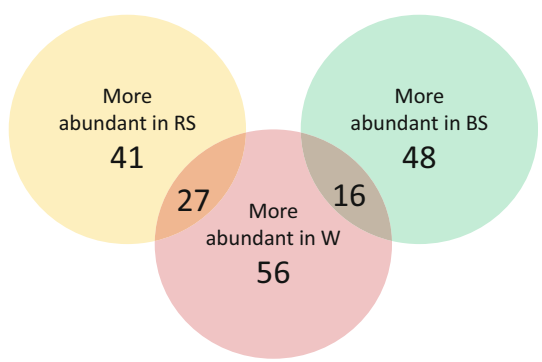

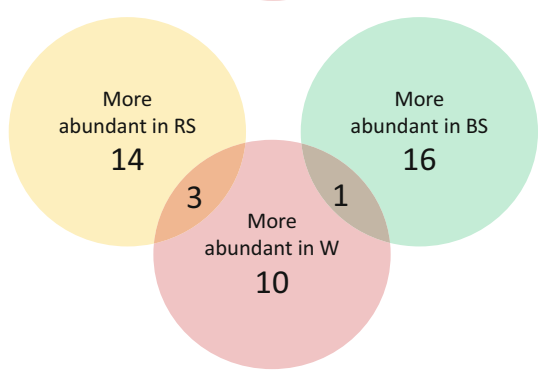


significantly more abundant in groundwater, constituted only $2 \%$ of OTUs with significantly greater abundance in wastewater-irrigated soils and Gemmatimonadetes constituted only $1 \%$. Conversely, Bacteroidetes, and $\alpha$ - and $\gamma$ Proteobacteria which were numerous in OTUs significantly more abundant in wastewater-irrigated soils constituted only 7.0, 7.0, and $8.7 \%$ respectively in groundwater-irrigated soils.

Differences were also observed in OTUs with significantly different abundance in bulk and rhizosphere soil compartments. In this case, rhizosphere soil was dominated by $\alpha$ Proteobacteria (30.9\% of OTUs with significantly greater abundance in rhizosphere soil) but this class represented only $10.9 \%$ of OTUs with significantly greater abundance in bulk soil. In bulk soil, $15.6 \%$ of OTUs having significantly greater abundance were classified as Acidobacteria compared to only $1.5 \%$ in rhizosphere soils and $9.4 \%$ were classified as Gemmatimonadetes in bulk soil compared to $1.5 \%$ in rhizosphere soil.

For fungi, the number of OTUs that showed significant increases in their abundance in groundwater-irrigated soil was higher than that in wastewater-irrigated soil. The number of OTUs associated with a significant increase in abundance in the rhizosphere and bulk soil was the same, similar to that found for the bacterial OTUs, but the numbers for fungi was less. Phyla responding to the different irrigation waters or soil compartments were also the same: Ascomycota, Basidiomycota, Chytridiomycota, and Zygomycota (Tables S9, S10, S11, and S12) indicating that the fungi probably originated from soil rather than from the irrigation water, and they were thus less sensitive to development of rhizospheres than bacteria. For OTUs showing significantly increased abundance in the rhizosphere, the number of OTUs showing significant increase under wastewater irrigation (3 OTUs) was higher than that under groundwater irrigation (0 OTU), while the opposite was true in the bulk soil.

\section{Relative abundance of $\mathrm{N}$-cycle-related genes}

\section{Water quality effects in rhizosphere and bulk soils}

The abundance of genes in the rhizosphere and bulk soil was significantly modulated by both water source and irrigation rate (Fig. 4, Tables 3 and 4). In considering N-cycle-related gene assemblages in the rhizosphere and bulk soils under different irrigation waters, unconstrained ordination based on the relative abundance of genes indicated separation between groundwater-irrigated and wastewater-irrigated soils (Fig. 5). In rhizosphere, groundwater irrigation and wastewater irrigation were separated on the first PCoA axis (associated with $84 \%$ of the variation in gene abundance). Assemblages in soils irrigated with wastewater appeared to differ considerably from the groundwater irrigation and vary more. This difference was less significant in bulk soil, where wastewater- and groundwater-irrigated soils were separated in the second PCoA axis (accounting for only 5\% of the variability). Twofactor PERMANOVA (Table 3) indicated a significant divergence in abundance of $\mathrm{N}$-cycle-related genes, dependent upon irrigation water source.

Similar patterns were repeated in the constrained ordination using RDA (Fig. 6), which identified strong and significant associations between $\mathrm{OM}$ and nifH, nitrate and bacterial amoA, nitrification rate and $n i r S$, as well as between $\mathrm{pH}$ and archaeal amoA in both rhizosphere and bulk soils. In the rhizosphere (Fig. $6 \mathrm{a}$, pseudo- $F=3.2, p=0.023$ ), the genes formed three groups: the first comprised of bacterial amoA, nirK, and nos $Z$, showing an increase in abundance with increased nitrate, denitrification rate, and at lower $\mathrm{pH}$ in wastewater-irrigated soils; the second, comprised of nirS and nifH showed a strong association with increased $\mathrm{OM}$ and nitrification rate resulting from wastewater irrigation; and the third group, comprised of archaeal amoA, showed a strong association with increased $\mathrm{pH}$ resulting from groundwater irrigation. These associations were associated with the principal RDA axis, which effectively separated wastewater- and groundwater-irrigated soils, and accounted for $60.5 \%$ of the variability described by the model. Soil $\mathrm{pH}$ (accounting for $22.5 \%$ of variability, pseudo- $F=6.4 ; p=0.006), \mathrm{OM}(21.9 \%$ of variability, $p$ seudo- $F=6.2 ; p=0.014)$, nitrate $(20.0 \%$ of variability, $p s e u d o-F=5.5 ; p=0.011$ ), and denitrification rate ( $18.4 \%$ of variability, $p$ seudo- $F=5.0 ; p=0.04$ ) were all associated with this separation by water source. No other environmental parameters were identified to account for the significant amount of variability, and only the Archeael amoA gene was associated with increases in $\mathrm{pH}-\mathrm{a}$ salient characteristic of groundwater-irrigated soil.

Such strong associations between environmental factors and gene abundance were not evident in bulk soils (Fig. 6b, pseudo$F=9.3, p=0.001$ ), where groundwater and wastewater treatments were separated on the second axis, and accounted for only $3.9 \%$ of the variability. Responses of the genes to irrigation were divergent in the bulk soil and there was no evidence of the gene groupings. On the second axis, the abundance of the nirS gene was associated with $\mathrm{C} / \mathrm{N}$ ratio and nitrification rate, while the abundance of nifH gene was associated with OM, but neither environmental parameter accounted for a significant amount of variability. An increase in nitrate concentration and reduction in $\mathrm{pH}$ did account for significant amounts of variability (nitrate $-39.4 \%$ of variability, $p s e u d o-F=14.3 ; p=0.002$; $\mathrm{pH}-23.7 \%$ of variability, $p s e u d o-F=6.8 ; p=0.012$ ) and were associated with an increase in bacterial amoA gene abundance and a decrease in archaeal amoA gene abundance; the abundance of nos $Z$ and nirK gene was associated with increases in EC (20.3\% of variability, $p s e u d o-F=5.6 ; p=0.015)$ and TN ( $16.3 \%$ of variability, $p s e u d o-F=4.3 ; p=0.046$ ), respectively. Nitrate and total $\mathrm{N}$ both increased under wastewater irrigation but appeared to be influenced differently by irrigation rate. 
Fig. 4 The abundance of N-cycle related genes in soil relative to the soil before fertilization and cultivation, and the gene abundance ratio of nosZ/nirK and nosZ/nirS. RS refers to rhizosphere, BS refers to bulk soil, G refers to groundwater, W refers to livestock wastewater, $\mathrm{C}$ refers to conventional furrow irrigation, A refers to alternate-furrow irrigation. $100,50,65$, and 80 refer to $100 \%, 50 \%, 65 \%$, and $80 \%$ of full irrigation amount per plot, respectively. The data are expressed as the mean \pm standard deviation. Different lower-case letters above the columns represent significant difference between treatments at $p<0.05$
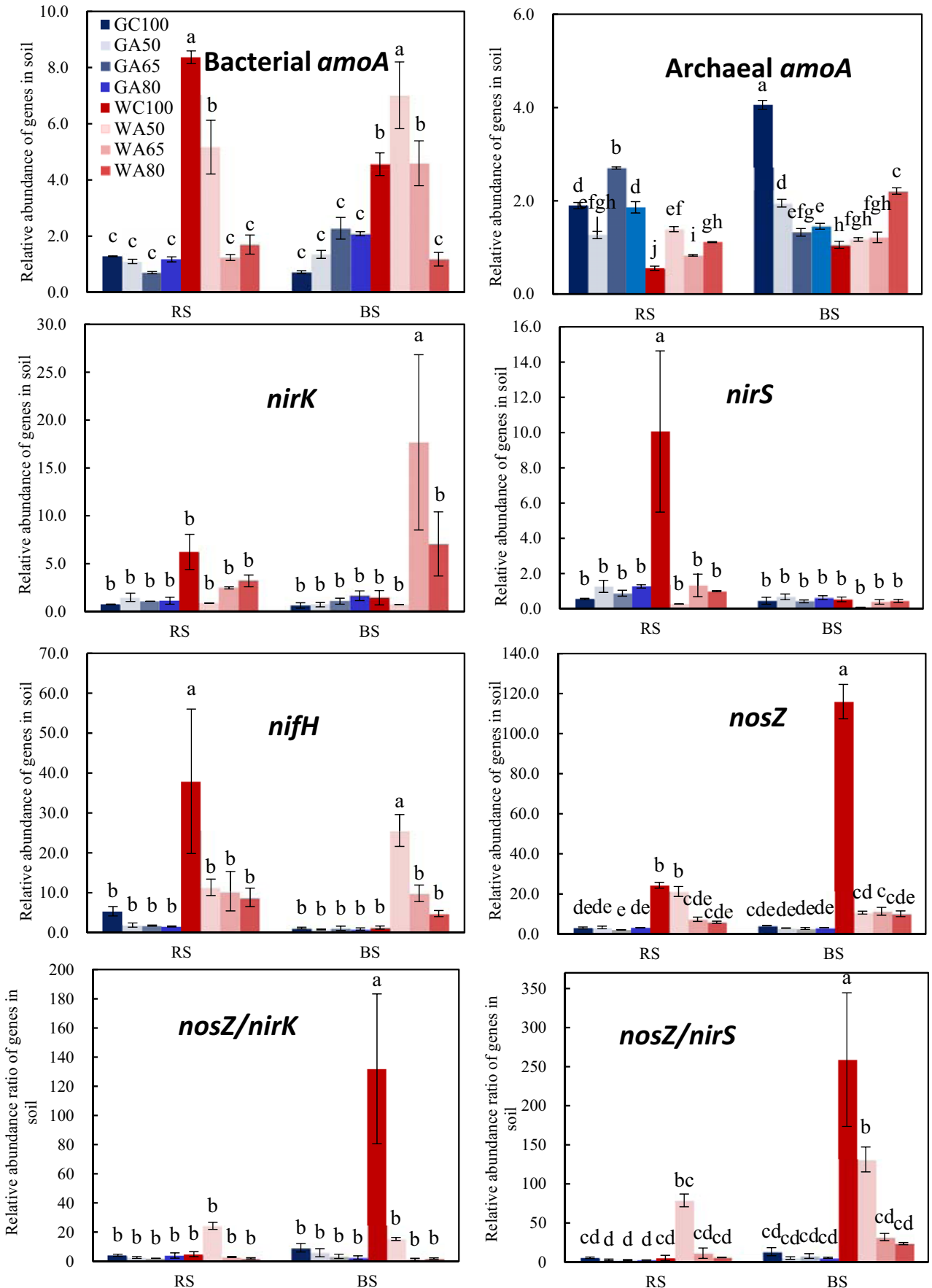

\section{The effects of alternate-furrow irrigation and irrigation amounts}

Gene abundance in soil under wastewater irrigation was higher than that under groundwater irrigation except for archaeal amoA (Fig. 4). PERMANOVA (Table 3) indicated there were significant differences in gene abundance at different irrigation rates regardless of water source which was more notable in the bulk soil than in the rhizosphere and evident on the second PCoA axis (Fig. 5). When irrigated with wastewater, relative to $\mathrm{CFI}, \mathrm{AFI}$ at $50 \%$ rate significantly reduced the abundance of bacterial amoA, nifH, and nirS in the rhizosphere, and nosZ, nosZ/nirK, and nosZ/nirS in the bulk soil, but increased the abundance of bacterial amoA and nifH in the bulk soil and archaeal amoA in rhizosphere (Fig. 4).

Irrigation rate had significant effects on the abundance of $\mathrm{N}$-cycle-related genes in the soils except for nifH in the rhizosphere and nirK and nirS in the bulk soil (Table 4). With reduced AFI rates, the abundance of nifH increased in both soil compartments. The abundance of nirK increased with the 
Table 3 Permutation multivariate analysis of variance of the relative abundance of all $\mathrm{N}$ cycling genes under different irrigation water sources, and different irrigation rates in the rhizosphere and bulk soil

\begin{tabular}{llrr}
\hline Soil compartment & Source of variation & \multicolumn{2}{l}{ Genes } \\
\cline { 3 - 4 } & & \multicolumn{1}{l}{$F$} & \multicolumn{1}{c}{$P$} \\
\hline Rhizosphere & Water source & 14.73 & $<0.001$ \\
& Irrigation amount & 3.76 & 0.002 \\
& Interaction & 2.73 & 0.018 \\
Bulk soil & Water source & 101.21 & $<0.001$ \\
& Irrigation amount & 60.20 & $<0.001$ \\
& Interaction & 57.77 & $<0.001$ \\
\hline
\end{tabular}

increase of water content in rhizosphere, but nirS did not respond in the same manner. In bulk soil, the nirK abundance also increased as irrigation rate increased from 50 to $65 \%$ and $80 \%$, but the variance of abundance in soil with higher rate were much higher. The bacterial amoA abundance increased in both soil compartments when the irrigation amount was reduced from high (80\% and $65 \%)$ to low $(50 \%)$, and the archaeal amoA abundance showed the same trend with bacterial $a m o A$ in rhizosphere while opposite in bulk soil. For the nos $Z$ gene - coding the nitrous-oxide reductase - the abundance at $50 \%$ rate was significantly higher than that at other two rates in rhizosphere. The nosZ/nirK and nosZ/nirS ratios has been widely used to estimate the likelihood of $\mathrm{N}_{2} \mathrm{O}$ emission (Pereira et al. 2015), and both ratios at 50\% rate of AFI using wastewater were higher than those at $65 \%$ and $80 \%$ rates in both soil compartments in which the differences of nosZ/nirS ratio in bulk soil were significant (Fig. 4), suggesting a reduced likelihood of $\mathrm{N}_{2} \mathrm{O}$ emission from denitrification.

\section{Discussion}

Nitrification rate in rhizosphere soil and plant $\mathrm{N}$ use efficiency were significantly influenced by water source but not by irrigation amount (Table S4), while water source and irrigation rate did not have significant impact on denitrification rate in either soil compartment. Community assemblages in irrigated soils were affected by the imposed treatments, with bacteria being far more sensitive to treatments than fungi, which only differed between soil compartments. Bacterial community assemblages in comparison were significantly impacted by irrigation water quality and soil compartment, but not irrigation rate. Regarding water quality, irrigation with wastewater has been found to increase nirK and nirS gene abundance compared to groundwater irrigation (Zhou et al. 2011). In several studies, microbial communities associated with rhizospheres were found to be distinct from those of the bulk soil. The separation of bacterial Phyla and Classes between groundwater- and wastewater-irrigated soil and the different soil compartments is consistent with general traits associated with the different Classes or Phyla. For example, Acidobacteria - which were more associated with groundwater irrigation and bulk soil- have been shown to be sensitive to nutrient concentrations and are more abundant under low nutrient conditions (Fierer et al. 2007). $\alpha$-Proteobacteria have the opposite response, increasing in abundance under increased nutrient conditions (Gravuer and Eskelinen 2017). This is consistent with their apparent association with wastewater-irrigation and the rhizosphere, where root exudates (Bais et al. 2006) and preference of plants for different nitrogen forms (Stempfhuber et al. 2017) influence microbial abundance. Irrigation rate did not have significant effects on bacterial community assemblages, but its impacts on gene abundance were striking. Soil compartment, water quality, and irrigation rate all had significant effects upon the relative abundance of the N-cycle-related genes.

\section{Irrigation effects on $\mathbf{N}$ transformation activities in soil}

Pepper yield was comparable in all treatments (Table S3). Compared to CFI, AFI with groundwater significantly increased N use efficiency of plants (Table S3). Since AFI wetted only half of the root zone during each irrigation, the difference in water matric potential between soils in the dry and wetted furrows could drive water to flow from the wetted half to the dry half across the root zone, increasing water and $\mathrm{N}$ use efficiency (Kang et al. 2000b). However, under wastewater

Table 4 Two-factor analysis of variance of gene abundance in rhizosphere (RS) and bulk soil (BS). Significant treatments effects are indicated in italic type

\begin{tabular}{|c|c|c|c|c|c|c|c|c|c|c|c|c|c|c|c|c|c|}
\hline & \multirow{2}{*}{$\begin{array}{l}\text { Source of } \\
\text { variation }\end{array}$} & \multicolumn{2}{|c|}{ Archaeal amoA } & \multicolumn{2}{|c|}{ Bacterial amoA } & \multicolumn{2}{|l|}{ nifH } & \multicolumn{2}{|l|}{$\operatorname{nir} K$} & \multicolumn{2}{|l|}{$\operatorname{nir} S$} & \multicolumn{2}{|l|}{$\operatorname{nos} Z$} & \multicolumn{2}{|c|}{ nosZ/nirK } & \multicolumn{2}{|c|}{ nosZ/nirS } \\
\hline & & $F$ & $P$ & $F$ & $P$ & $F$ & $P$ & $F$ & $P$ & $F$ & $P$ & $F$ & $P$ & $F$ & $P$ & $F$ & $P$ \\
\hline \multirow[t]{3}{*}{ RS } & Wat & .93 & $<0$ & 134.78 & $<1$ & & & 17.04 & & 3.49 & & & & 25 & & 61.20 & \\
\hline & Irrigation am & 28.83 & $<0.001$ & 44.47 & $<0.001$ & 2.72 & 0.079 & 3.73 & 0.033 & 3.47 & 0.041 & 36.38 & & 32.21 & & 40.10 & $<0.001$ \\
\hline & Interaction & 95.30 & $<0.001$ & 36.09 & $<0.001$ & 1.62 & 0.225 & 6.30 & 0.005 & 4.51 & 0.018 & 32.85 & $<0.001$ & 36.90 & $<0.001$ & 41.73 & $<0.001$ \\
\hline \multirow[t]{3}{*}{ BS } & Water source & 192.45 & $<0.001$ & 48.55 & $<0.001$ & 66.03 & $<0.001$ & 5.40 & 0.034 & 4.19 & 0.058 & 226.84 & $<0.001$ & 6.30 & 0.023 & 22.53 & $<0.001$ \\
\hline & Irrigation amount & 95.33 & $<0.001$ & 7.82 & 0.002 & 21.09 & $<0.001$ & 2.70 & 0.081 & 0.66 & 0.588 & 141.02 & $<0.001$ & 6.56 & 0.004 & 6.69 & 0.004 \\
\hline & Interaction & 202.20 & $<0.001$ & 12.65 & $<0.001$ & 22.12 & $<0.001$ & 2.43 & 0.103 & 2.73 & 0.078 & 134.78 & $<0.001$ & 5.51 & 0.009 & 6.00 & 0.0 \\
\hline
\end{tabular}


Fig. 5 Unconstrained principal coordinate analysis of N-cyclerelated genes based on relative abundance using Euclidean distance metrics in rhizosphere (a) and bulk soil (b). G refers to groundwater, $\mathrm{W}$ refers to livestock wastewater, $\mathrm{C}$ refers to conventional furrow irrigation, $\mathrm{A}$ refers to alternate-furrow irrigation. $50,65,80$, and 100 refer to $50 \%, 65 \%, 80 \%$, and $100 \%$ of full irrigation amount per plot, respectively
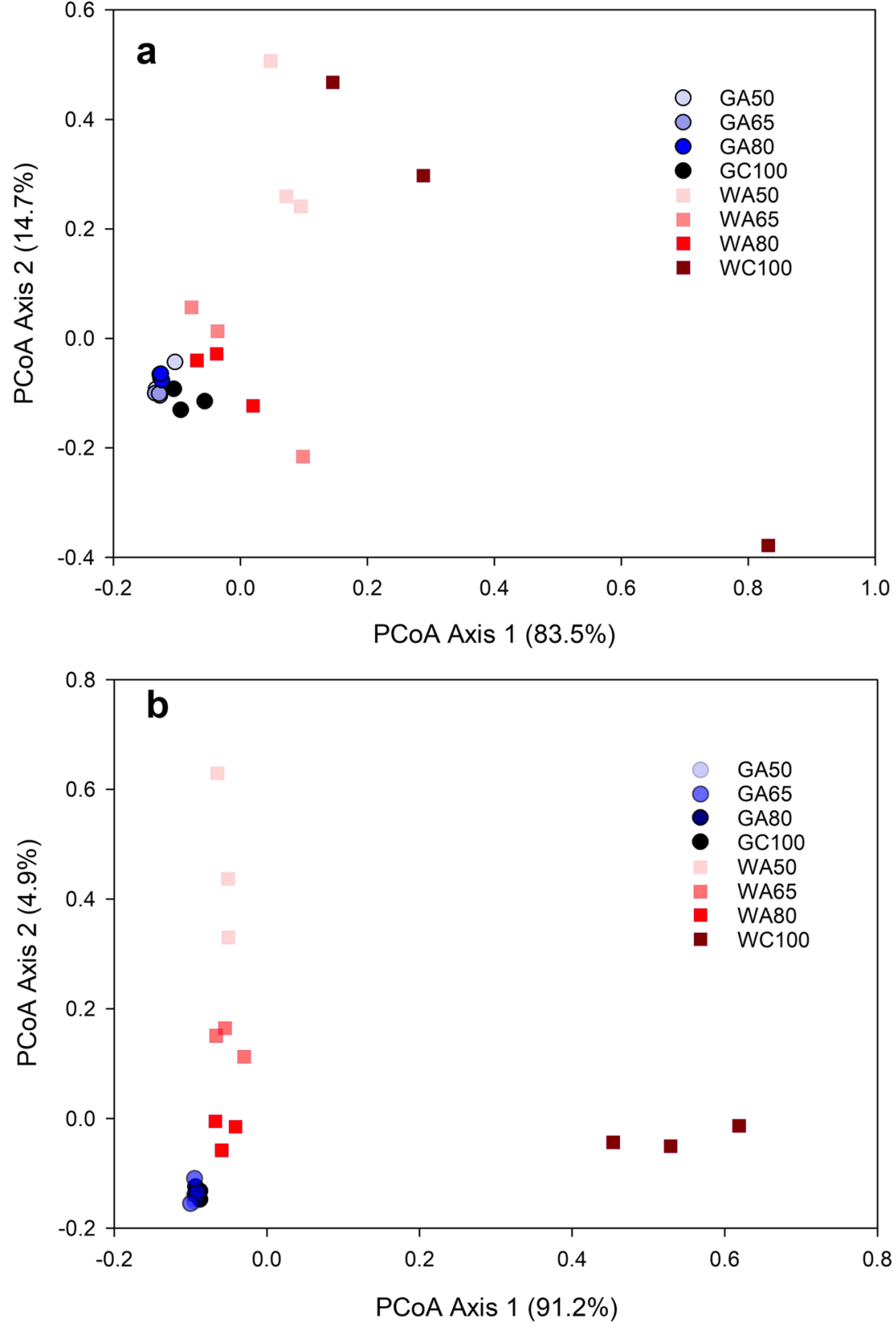

irrigation, the irrigation method and amount did not have significant effects on $\mathrm{N}$ use efficiency (Table S3), suggesting that the $\mathrm{N}$ input exceeded the uptake of plants, even at the lowest AFI rate. Though $\mathrm{N}$ use efficiency was not affected by irrigation amount significantly (Table S4), the highest efficiency was achieved at $80 \%$ AFI rate using groundwater (Table S3).

The higher AFI rate $(80 \%)$ also boosted nitrification activity in both soil compartments regardless of water source (Fig. 1), indicating a reduction in ammonia volatilization losses and an increase in nitrate for denitrification. Denitrification activity did not increase $\mathrm{N}$ losses because the denitrification rates under $80 \%$ AFI treatments were not increased compared to that under other two AFI rates (Fig. 1).
As a result of the high plant $\mathrm{N}$ uptake under $80 \%$ AFI rate as discussed above, $\mathrm{NO}_{3}{ }^{-}-\mathrm{N}$ was not significantly accumulated in the soils (Table 2). Total $\mathrm{N}$ content in $80 \%$ rate of AFI with wastewater was increased compared to those in other treatments in both soil compartments, and significantly higher than that in CFI and 65\% AFI rate in rhizosphere (Table 2), suggesting that soil fertility may have been improved.

The presence of $\mathrm{N}$-cycle genes in the soils does not indicate gene expression. Neither the abundance of bacterial amoA, archaeal $a m o A$, and nitrification rate nor the abundance of nir $K$, nir $S, n o s Z$, and denitrification rate responded similarly to the irrigation methods. Because we targeted soil DNA, the measured gene abundance was not equivalent to actual $\mathrm{N}$ 

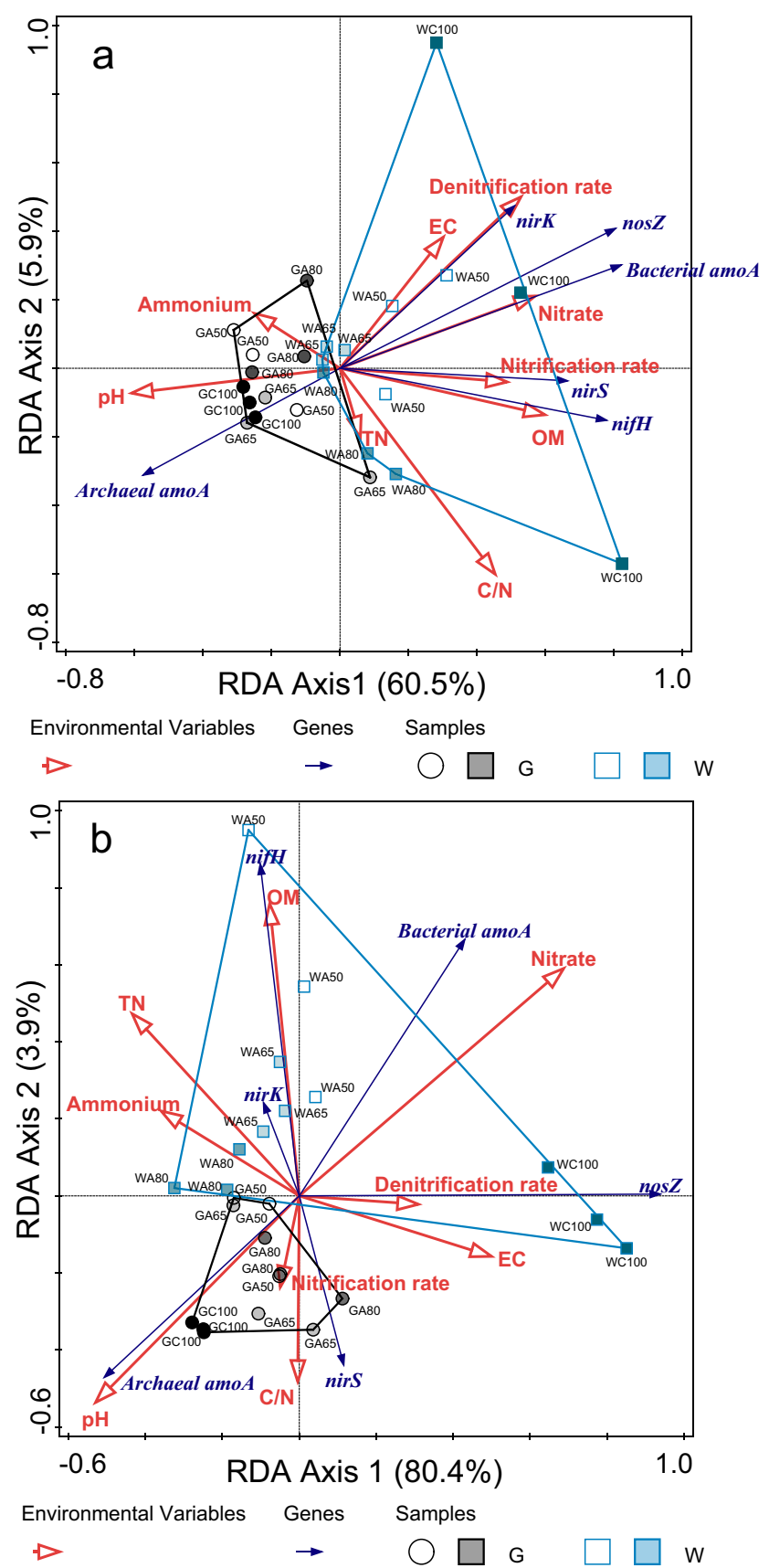

Fig. 6 Redundancy Analysis presenting the association of N-cyclerelated gene abundance with environmental factors in rhizosphere (a) and bulk soil (b). G refers to groundwater, W refers to livestock wastewater. $\mathrm{C}$ refers to conventional furrow irrigation, A refers to alternatefurrow irrigation. $50,65,80$, and 100 refer to $50 \%, 65 \%, 80 \%$, and $100 \%$ of full irrigation amount per plot, respectively

transformation activity or mRNA concentration (Bowen et al. 2018). While nif $H$ genes were detected in our soils, $\mathrm{N}$ fixation was not, consistent with previous studies (Kumar et al. 2017; Wang et al. 2018). The ability of bacteria to fix $\mathrm{N}$ is controlled not only by the abundance of organisms carrying nifH gene but also by other conditions. Diazotrophs carrying nifH gene favor low $\mathrm{N}$ habitat, but synthesizing the nitrogenase enzyme is an energetically expensive process and limited by iron, phosphorus, or other nutrients (Larson et al. 2018).

When the wastewater used in AFI increased from 50 to $80 \%$, the abundance of bacterial $a m o A$ and archaeal $a m o A$ in rhizospheres decreased significantly (Fig. 4), but the nitrification rate did not decrease (Fig. 1), suggesting that the AFI might have altered the bioavailability of water and other substrates, rendering microbial activity at low rate $(50 \%)$ differing from that at high rate $(80 \%)$. Though the differences in nitrification rate in wastewater-irrigated soils between the three AFI treatments were not significant, the nitrification rate at $80 \%$ treatment was higher than that at $50 \%$ and $65 \%$ treatments which made sense for agricultural production. At the $80 \%$ rate, the water supply rate exceeded soil infiltration rate, giving rise to surface runoff. As a result, there was no significant difference in soil water content between the irrigated and non-irrigated furrows, and soil ammonium availability was high for nitrifiers. In contrast, at the $50 \%$ rate, the water supply rate was low and only wetted part of the root zone, hence the available ammonium was rather low. Consequently, the $80 \%$ AFI rate enhanced nitrification activity even when the abundance of associated genes was low.

The enhanced nitrification activity under $80 \%$ AFI rate increased the production of nitrate, but possibly because of leaching, there was no associated increase in nitrate for denitrification. Thus, it was not surprising that we did not find increased $\mathrm{NO}_{3}{ }^{-}-\mathrm{N}$ content in both rhizosphere and bulk soil under $80 \%$ rate compared to $50 \%$ and $65 \%$ rates (Table 2). Therefore, the denitrification rate under $80 \%$ AFI was comparable to that under other two AFI treatments (Fig. 1) even the abundance of nirK and nirS in the former was slightly higher than that in the latter (Fig. 4). Above results implicate that $80 \%$ AFI rate could increase N use efficiency due to a balance between water, oxygen, and available $\mathrm{N}$ in soil.

\section{Association of enumerated genes with soil chemical parameters}

Quantification of relative gene abundance indicated that $\operatorname{nirK}$ and nos $Z$ genes were most abundant in bulk soil, and nifH and nir $S$ most abundant in the rhizosphere (Fig. 4). Bacterial and archaeal amoA were equally abundant in both soil compartments (Fig. 4). This suggests spatial separation of N-cyclerelated processes, possibly driven by plant root activity. Gene $a m o A$, a bioindicator of nitrification potential, was ubiquitous in the soils and the abundance of bacterial and archaeal amoA were associated with the increased $\mathrm{NO}_{3}{ }^{-} \mathrm{N}$ and $\mathrm{pH}$ respectively (from RDA, Fig. 6). The abundance of bacterial and archaeal amoA typically respond to environmental change differently. For example, Han et al. (2017) reported the irrigation amount significantly influenced the copy number of archaeal amoA, but not of bacterial amoA in soil. The influence was clearly correlated with the change of soil 
temperature, water-filled pore space (Liu et al. 2017), $\mathrm{pH}$, $\mathrm{NO}_{3}{ }^{-}-\mathrm{N}$, exchangeable $\mathrm{NH}_{4}{ }^{+}-\mathrm{N}$, and potential nitrification rates. Bacterial amoA populations are typically found in greater abundance in agricultural soils, particularly soils with higher fertilizer inputs and soil disturbance (Bruns et al. 1999; Di et al. 2010), while archaeal amoA dominates ammonia oxidation at lower $\mathrm{N}$ concentrations (Martens-Habbena et al. 2009) and in undisturbed soils (Nicol et al. 2008). For our experiment, archaeal amoA was more abundant in groundwater-irrigated soils with higher $\mathrm{pH}$ and lower concentration of $\mathrm{NO}_{3}{ }^{-}-\mathrm{N}$ (Fig. 6). However, it is clear from Fig. 6 that bacterial amoA specifically responded to the greater nutrient addition arising from wastewater-irrigation in both soil compartments. This response to added nutrients is consistent with observations of increased bacterial amoA numbers in response to urea addition in soil (Reed et al. 2010; Shen et al. 2011).

The abundance of nirK and nos $Z$ genes associated with denitrification rate were also associated with increased $\mathrm{NO}_{3}{ }^{-}$-N concentration in rhizosphere (Fig. 6a), but were most abundant in bulk soil (Fig. 4). The nirK and nirS genes both regulate transformation of nitrite to nitric oxide, but they are carried by phylogenetically distinct organisms with different niche preferences, and responded to $\mathrm{C} / \mathrm{N}$ ratio differently (Fig. 6) (Bowen et al. 2018). Quantitative-PCR (Fig. 4) indicated that both abundance of nirK and nirS attained a maximum in the same treatment (WC100) in rhizosphere, but in bulk soil, the abundance difference of nirK between WA65, WA80, and other treatments were much greater than that of nirS, suggesting that the abundance of nirK was the more responsive functional gene associated with nitrite reduction, as confirmed by Fig. 6a that nirK abundance but not nirS abundance was closely associated with denitrification rate. Some studies also confirmed that the nirK-denitrifying bacterial community was more sensitive to environmental changes (Wertz et al. 2013; Yin et al. 2015). However, one wheatgrowing field experiment in a sandy clay loam revealed that nirS- and nosZ-denitrifying bacterial communities were more sensitive to irrigation managements than nirK-denitrifying bacteria (Yang et al. 2018). Denitrification is an anaerobic process and nirK and nirS abundance in the rhizosphere increased with the increase in irrigation amount generally (Fig. 4). In the bulk soil, the $50 \%$ irrigation treatment was associated with the lowest nirK and nirS relative abundance, but nirK abundance in $100 \%$ CFI treatment was also low compared with $65 \%$ and $80 \%$ AFI treatments (Fig. 4), possibly because the high spatial heterogeneity of bulk soil due to heterogeneous water distribution.

The identification of the $\mathrm{N}_{2} \mathrm{O}$ reductase gene (nos $Z$ ) by qPCR in soil indicated the potential for complete denitrification, thus it is not surprising that the abundance of nos $Z$ gene was associated with denitrification rate in bulk soil. $\mathrm{N}_{2} \mathrm{O}$ is a product of both nitrification and denitrification, depending on soil moisture, oxygen, and other environmental factors (Arp and Stein 2003; Ma et al. 2008), therefore an association between bacterial amoA and nos $Z$ in rhizosphere in our study (Fig. 6) is reasonable. Nitrification was the main driver of nitrous oxide production in the $0-$ to $5-\mathrm{cm}$ and $5-$ to $10-\mathrm{cm}$ soil layers while denitrification was in the $10-$ to $15-\mathrm{cm}$ and 15- to 20-cm soil horizons (Castellano-Hinojosa et al. 2018). It has been reported that alternating wetting and drying during the rice season in a field rice-wheat rotation system in a paddy soil increased soil aeration status thus increased $\mathrm{N}_{2} \mathrm{O}$ emissions from simultaneous nitrification and denitrification during the rice season compared to traditional flooding irrigation (Hou et al. 2016). But flooding lowered soil organic $\mathrm{N}$ mineralization during the rice season, thus more mineral $\mathrm{N}$ in soil was available to $\mathrm{N}_{2} \mathrm{O}$ production and significantly reduced $\mathrm{N}_{2} \mathrm{O}$ emissions in the following wheat season compared to traditional irrigation. The $\mathrm{N}_{2} \mathrm{O}$ reduction to $\mathrm{N}_{2}$ is favored at low redox potential $\left(E_{\mathrm{h}}\right)$, and the lower $E_{\mathrm{h}}$ was associated with increased soil moisture (Liu et al. 2012), which could contribute to the high abundance of nos $Z$ in $100 \%$ CFI treatment in our study (Fig. 4).

The nitrogenase iron protein gene $n i f H$ is an indicator of $\mathrm{N}_{2}$ fixation potential (Wang et al. 2018). The gene was correlated with increased $\mathrm{OM}$ content and reduced concentrations of exchangeable $\mathrm{NH}_{4}{ }^{+}-\mathrm{N}$ in wastewater-irrigated rhizospheres (Fig. 6). This suggests a high biological demand for $\mathrm{N}$ in the rhizosphere, rich in organic matter, which could not be satisfied by the available $\mathrm{NH}_{4}{ }^{+}-\mathrm{N}$ and so $\mathrm{N}_{2}$ fixation may be used to supplement this high demand. The exchangeable $\mathrm{NH}_{4}{ }^{+}-\mathrm{N}$ content in soil increased with AFI rate (Table 2), which may explain the change in nifH abundance with the AFI rate (Fig. 4). A second gene, nirS, was also associated with increased organic matter in wastewater receiving rhizosphere soil, and showed correlation with nifH (Fig. 6a). Since the NirS protein, encoded by nirS, has a secondary function as a hydroxylamine $\left(\mathrm{NH}_{2} \mathrm{OH}\right)$ reductase (https://www.kegg.jp/ dbget-bin/www_bget?K05601+K15864+1.7.99.1+R00143) (Rees et al. 1997; Zumft 1997), which also produces ammonium, it is possible that nirS and nifH were coupled in response to the decrease in ammonium and that $\operatorname{nir} S$ was associated with nitrification rate (Fig. 6).

\section{Fungal contribution to $\mathbf{N}$ cycling}

Nitrogen metabolism in soil is typically associated overwhelmingly with bacterial or archaeal activity. However, fungi may also play a role in these processes which should receive more attention. The primers employed in our study are unlikely to amplify fungal genes, but the effects of fungi cannot be ignored. Many fungal species are known to produce $\mathrm{N}_{2} \mathrm{O}$ (Shoun et al. 1992; Wei et al. 2014). For example, studies have revealed that Fusarium oxysporum and Cylindrocarpon tonkinese use NirK to reduce nitrite to nitric oxide (Nakanishi et al. 2010), and fungal nirK has close homology 
to its bacterial ortholog (Kobayashi and Shoun 1995; Kim et al. 2010). A fungal nirK primer set nirKfF/nirKfR (Wei et al. 2015) detected nirK of Ascomycota, the dominant denitrifying fungal group in soil, and when amplified using these fungal primers, nirK clones showed homology to nirK of Hypocreales, Sordariales, and Eurotiales of Ascomycota. In this study, the Ascomycota phylum was also identified by amplicon sequencing as having significantly higher abundance in soil regardless of water source (Tables S9-S12). Fungi are also indispensable in $\mathrm{N}$ mineralization and nitrification (Lang and Jagnow 1986; Boer and Kowalchuk 2001; DeCrappeo et al. 2017), and contribute more to $\mathrm{N}_{2} \mathrm{O}$ production under sub-anoxic and acidic conditions than bacteria (Chen et al. 2015).

\section{Conclusions}

Our research studied differences in $\mathrm{N}$ transformation activities and the associated $\mathrm{N}$ cycling genes distribution in soil following AFI and CFI, comparing groundwater and wastewater sources at different irrigation rates. Compared with CFI, AFI using groundwater increased plant $\mathrm{N}$ use efficiency. Water quality had a manifest effect on the propagation of genes abundances: the genes were more responsive to irrigation with wastewater than groundwater. AFI using wastewater reduced the gene abundances in rhizosphere except archaeal amoA relative to CFI. Under AFI with wastewater, increasing the irrigation amount could increase the abundance of nirK and nirS and decrease the abundance of bacterial and archaeal amoA, nifH, and nosZ in rhizosphere, but did not decrease the nitrification rate and kept the denitrification rate unchanged in both rhizosphere and bulk soil, revealing that the irrigation amounts with AFI did not change $\mathrm{N}$ transformation processes and the abundance of associated $\mathrm{N}$-cycle genes in soil synchronously. We conjectured from our findings that some biophysicochemical processes unique to roots induced by water stress under different AFI rates might contribute to the desynchrony between the $\mathrm{N}$ transformation processes and the associated $\mathrm{N}$-cycle genes in soil.

We measured the properties of soil only at the harvest and could not get the dynamics of $\mathrm{N}$ transformation and gene abundance during the irrigation management. However, the effects of AFI with different irrigation rates on $\mathrm{N}$ transformation and gene abundance in soil were clear. Our results have important applications that appropriate irrigation rate in AFI have the potential to increase the $\mathrm{N}$ use efficiency.

Acknowledgments This study was financially supported by the National Natural Science Foundation of China (41701265), the Scientific and Technological Project of Henan Province (172102110121), the Central Public-interest Scientific Institution Basal Research Fund (Chinese Academy of Agricultural Sciences) (FIRI2016-13 and Y2019GH19), the National Key Research and Development Program of China
(2017YFD0801103-2), the National Natural Science Foundation of China (51479201), the Agricultural Science and Technology Innovation Program (ASTIP) of Chinese Academy of Agricultural Sciences, and the China Scholarship Council. Work at Rothamsted Research is supported by the United Kingdom Biotechnology and Biological Science Research Council (BBSRC)-funded Soil to Nutrition strategic programme (BBS/E/ C/000I0310) and jointly by the Natural Environment Research Council and BBSRC as part of the Achieving Sustainable Agricultural Systems research programme (BBS/E/C/000I0130).

\section{Compliance with ethical standards}

Conflict of interest The authors declare that they have no conflict of interest.

Open Access This article is distributed under the terms of the Creative Commons Attribution 4.0 International License (http:// creativecommons.org/licenses/by/4.0/), which permits unrestricted use, distribution, and reproduction in any medium, provided you give appropriate credit to the original author(s) and the source, provide a link to the Creative Commons license, and indicate if changes were made.

\section{References}

Anderson MJ, Walsh DCI (2013) PERMANOVA, ANOSIM, and the mantel test in the face of heterogeneous dispersions: what null hypothesis are you testing? Ecol Monogr 83:557-574. https://doi.org/ $10.1890 / 12-2010.1$

Arp DJ, Stein LY (2003) Metabolism of inorganic N compounds by ammonia-oxidizing bacteria. Crit Rev Biochem Mol Biol 38:471495

Azziz G, Monza J, Etchebehere C, Irisarri P (2017) nirS- and nirK-type denitrifier communities are differentially affected by soil type, rice cultivar and water management. Eur J Soil Biol 78:20-28. https:// doi.org/10.1016/j.ejsobi.2016.11.003

Bais HP, Weir TL, Perry LG, Gilroy S, Vivanco JM (2006) The role of root exudates in rhizosphere interactions with plants and other organisms. Annu Rev Plant Biol 57:233-266. https://doi.org/10.1146/ annurev.arplant.57.032905.105159

Berger S, Jang I, Seo J, Kang H, Gebauer G (2013) A record of $\mathrm{N}_{2} \mathrm{O}$ and $\mathrm{CH}_{4}$ emissions and underlying soil processes of Korean rice paddies as affected by different water management practices. Biogeochemistry 115:317-332. https://doi.org/10.1007/s10533013-9837-1

Boer W, Kowalchuk G (2001) Nitrification in acid soils: micro-organisms and mechanisms. Soil Biol Biochem 33:853-866. https://doi.org/10. 1016/s0038-0717(00)00247-9

Bowen H, Maul JE, Poffenbarger H, Mirsky S, Cavigelli M, Yarwood S (2018) Spatial patterns of microbial denitrification genes change in response to poultry litter placement and cover crop species in an agricultural soil. Biol Fertil Soils 54:769-781. https://doi.org/10. 1007/s00374-018-1301-x

Bruns MA, Stephen JR, Kowalchuk GA, Prosser JI, Paul EA (1999) Comparative diversity of ammonia oxidizer 16S rRNA gene sequences in native, tilled, and successional soils. Appl Environ Microbiol 65:2994-3000. https://doi.org/10.1073/pnas.0406616101

Cai T, Park SY, Li Y (2013) Nutrient recovery from wastewater streams by microalgae: status and prospects. Renew Sust Energ Rev 19:360 369

Caporaso JG, Kuczynski J, Stombaugh J, Bittinger K, Bushman FD, Costello EK, Fierer N, Peña AG, Goodrich JK, Gordon JI, Huttley GA, Kelley ST, Knights D, Koenig JE, Ley RE, Lozupone CA, McDonald D, Muegge BD, Pirrung M, Reeder J, Sevinsky JR, 
Turnbaugh PJ, Walters WA, Widmann J, Yatsunenko T, Zaneveld J, Knight R (2010) QIIME allows analysis of high-throughput community sequencing data. Nat Methods 7:335-336

Castellano-Hinojosa A, González-López J, Bedmar EJ (2018) Distinct effect of nitrogen fertilisation and soil depth on nitrous oxide emissions and nitrifiers and denitrifiers abundance. Biol Fertil Soils 54: 829-840. https://doi.org/10.1007/s00374-018-1310-9

Chen HH, Mothapo NV, Shi W (2015) Soil moisture and pH control relative contributions of fungi and bacteria to $\mathrm{N}_{2} \mathrm{O}$ production. Microb Ecol 69:180-191

de Sosa LL, Glanville HC, Marshall MR, Williams AP, Abadie M, Clark IM, Blaud A, Jones DL (2018) Spatial zoning of microbial functions and plant-soil nitrogen dynamics across a riparian area in an extensively grazed livestock system. Soil Biol Biochem 120:153-164. https://doi.org/10.1016/j.soilbio.2018.02.004

DeCrappeo NM, DeLorenze EJ, Giguere AT, Pyke DA, Bottomley PJ (2017) Fungal and bacterial contributions to nitrogen cycling in cheatgrass-invaded and uninvaded native sagebrush soils of the western USA. Plant Soil 416:271-281. https://doi.org/10.1007/ s11104-017-3209-x

Dhariwal A, Chong J, Habib S, King IL, Agellon LB, Xia J (2017) MicrobiomeAnalyst: a web-based tool for comprehensive statistical, visual and meta-analysis of microbiome data. Nucleic Acids Res 45: W180-W188. https://doi.org/10.1093/nar/gkx295

Di HJ, Cameron KC, Shen JP, Winefield CS, O'Callaghan M, Bowatte S, He JZ (2010) Ammonia-oxidizing bacteria and archaea grow under contrasting soil nitrogen conditions. FEMS Microbiol Ecol 72:386394. https://doi.org/10.1111/j.1574-6941.2010.00861.x

Dong X, Reddy GB (2012) Ammonia-oxidizing bacterial community and nitrification rates in constructed wetlands treating swine wastewater. Ecol Eng 40:189-197. https://doi.org/10.1016/j.ecoleng.2011.12. 022

Dong LF, Smith CJ, Papaspyrou S, Stott A, Osborn AM, Nedwell DB (2009) Changes in benthic denitrification, nitrate ammonification, and anammox process rates and nitrate and nitrite reductase gene abundances along an estuarine nutrient gradient (the Colne estuary, United Kingdom). Appl Environ Microbiol 75:3171-3179. https:// doi.org/10.1128/AEM.02511-08

Fierer N, Bradford MA, Jackson RB (2007) Toward an ecological classification of soil bacteria. Ecology 88:1354-1364. https://doi.org/10. 1890/05-1839

Gao B, Huang T, Ju X, Ju X, Gu B, Huang W, Xu L, Rees RM, Powlson DS, Smith P, Cui S (2018) Chinese cropping systems are a net source of greenhouse gases despite soil carbon sequestration. Glob Chang Biol 24:5590-5606. https://doi.org/10.1111/gcb.14425

Graterol YE, Eisenhauer DE, Elmore RW (1993) Alternate-furrow irrigation for soybean production. Agric Water Manag 24:133-145. https://doi.org/10.1016/0378-3774(93)90004-T

Gravuer K, Eskelinen A (2017) Nutrient and rainfall additions shift phylogenetically estimated traits of soil microbial communities. Front Microbiol 8:8. https://doi.org/10.3389/fmicb.2017.01271

Han K, Zhou C, Wang L, Si J (2014) Effect of alternating furrow irrigation and nitrogen fertilizer on nitrous oxide emission in corn field. Commun Soil Sci Plant Anal 45:592-608. https://doi.org/10.1080/ 00103624.2013.874019

Han B, Ye X, Li W, Zhang X, Zhang Y, Lin X, Zou H (2017) The effects of different irrigation regimes on nitrous oxide emissions and influencing factors in greenhouse tomato fields. J Soils Sediments 17:2457-2468. https://doi.org/10.1007/s11368-017-1700-x

Henry S, Bru D, Stres B, Hallet S, Philippot L (2006) Quantitative detection of the nos $Z$ gene, encoding nitrous oxide reductase, and comparison of the abundances of $16 \mathrm{~S}$ rRNA, $\operatorname{nar} G, \operatorname{nirK}$, and $\operatorname{nos} Z$ genes in soils. Appl Environ Microbiol 72:5181-5189. https://doi. org/10.1128/AEM.00231-06

Hou H, Yang S, Wang F, Li D, Xu J (2016) Controlled irrigation mitigates the annual integrative global warming potential of methane and nitrous oxide from the rice-winter wheat rotation systems in Southeast China. Ecol Eng 86:239-246. https://doi.org/10.1016/j. ecoleng.2015.11.022

Hu HW, Chen D, He JZ (2015) Microbial regulation of terrestrial nitrous oxide formation: understanding the biological pathways for prediction of emission rates. FEMS Microbiol Rev 39:729-749

Huang X, Liu L, Wen T, Zhang J, Wang F, Cai Z (2016) Changes in the soil microbial community after reductive soil disinfestation and cucumber seedling cultivation. Appl Microbiol Biotechnol 100:55815593. https://doi.org/10.1007/s00253-016-7362-6

Kang S, Liang Z, Pan Y, Shi P, Zhang J (2000a) Alternate furrow irrigation for maize production in an arid area. Agric Water Manag 45: 267-274. https://doi.org/10.1016/S0378-3774(00)00072-X

Kang SZ, Shi P, Pan YH, Liang ZS, Hu XT, Zhang J (2000b) Soil water distribution, uniformity and water-use efficiency under alternate furrow irrigation in arid areas. Irrig Sci 19:181-190. https://doi.org/10. 1007/s002710000019

Kim S-W, Fushinobu S, Zhou S, Wakagi T, Shoun H (2010) The possible involvement of copper-containing nitrite reductase (NirK) and flavohemoglobin in denitrification by the fungus Cylindrocarpon tonkinense. Biosci Biotechnol Biochem 74:1403-1407. https://doi. org/10.1271/bbb.100071

Kobayashi M, Shoun H (1995) The copper-containing dissimilatory nitrite reductase involved in the denitrifying system of the fungus Fusarium oxysporum. J Biol Chem 270:4146-4151. https://doi. org/10.1074/jbc.270.8.4146

Könneke M, Bernhard AE, De La Torre JR, Walker CB, Waterbury JB, Stahl DA (2005) Isolation of an autotrophic ammonia-oxidizing marine archaeon. Nature 437:543-546. https://doi.org/10.1038/ nature 03911

Krauss M, Krause HM, Spangler S, Kandeler E, Gattinger A (2017) Tillage system affects fertilizer-induced nitrous oxide emissions. Biol Fertil Soils 53:49-59. https://doi.org/10.1007/s00374-016$1152-2$

Kumar U, Panneerselvam P, Govindasamy V, Vithalkumar L, Senthilkumar M, Banik A, Annapurna K (2017) Long-term aromatic rice cultivation effect on frequency and diversity of diazotrophs in its rhizosphere. Ecol Eng 101:227-236. https://doi.org/10.1016/j. ecoleng.2017.02.010

Lang E, Jagnow G (1986) Fungi of a forest soil nitrifying at low $\mathrm{pH}$ values. FEMS Microbiol Lett 38:257-265. https://doi.org/10.1016/ 0378-1097(86)90001-7

Larson CA, Mirza B, Rodrigues JLM, Passy SI (2018) Iron limitation effects on nitrogen-fixing organisms with possible implications for cyanobacterial blooms. FEMS Microbiol Ecol 94. https://doi.org/10. 1093/femsec/fiy046

Leaw SN, Chang HC, Sun HF, Barton R, Bouchara JP, Chang TC (2006) Identification of medically important yeast species by sequence analysis of the internal transcribed spacer regions. J Clin Microbiol 44:693-699. https://doi.org/10.1128/JCM.44.3.693-699.2006

Li Z, Tang S, Deng X, Wang R, Song Z (2010) Contrasting effects of elevated $\mathrm{CO}_{2}$ on $\mathrm{Cu}$ and $\mathrm{Cd}$ uptake by different rice varieties grown on contaminated soils with two levels of metals: implication for phytoextraction and food safety. J Hazard Mater 177:352-361. https://doi.org/10.1016/j.jhazmat.2009.12.039

Li X, Zhang M, Liu F, Chen L, Li Y, Li Y, Xiao R, Wu J (2018) Seasonality distribution of the abundance and activity of nitrification and denitrification microorganisms in sediments of surface flow constructed wetlands planted with Myriophyllum elatinoides during swine wastewater treatment. Bioresour Technol 248:89-97. https:// doi.org/10.1016/j.biortech.2017.06.102

Liu J, Hou H, Sheng R, Chen Z, Zhu Y, Qin H, Wei W (2012) Denitrifying communities differentially respond to flooding drying cycles in paddy soils. Appl Soil Ecol 62:155-162. https://doi.org/10. 1016/j.apsoil.2012.06.010 
Liu R, Hayden HL, Suter H, Hu H, Lam SK, He J, Mele PM, Chen D (2017) The effect of temperature and moisture on the source of $\mathrm{N}_{2} \mathrm{O}$ and contributions from ammonia oxidizers in an agricultural soil. Biol Fertil Soils 53:141-152. https://doi.org/10.1007/s00374-016-1167-8

Livak KJ, Schmittgen TD (2001) Analysis of relative gene expression data using real-time quantitative PCR and the $2^{-\Delta \Delta C T}$ method. Methods 25:402-408. https://doi.org/10.1006/meth.2001.1262

Love MI, Huber W, Anders S (2014) Moderated estimation of fold change and dispersion for RNA-seq data with DESeq2. Genome Biol 15:550. https://doi.org/10.1186/s13059-014-0550-8

Lozupone C, Lladser ME, Knights D, Stombaugh J, Knight R (2011) UniFrac: an effective distance metric for microbial community comparison. ISME J 5:169-172

Ma WK, Bedard-Haughn A, Siciliano SD, Farrell RE (2008) Relationship between nitrifier and denitrifier community composition and abundance in predicting nitrous oxide emissions from ephemeral wetland soils. Soil Biol Biochem 40:1114-1123. https:// doi.org/10.1016/j.soilbio.2007.12.004

Malvick DK, Impullitti AE (2007) Detection and quantification of Phialophora gregata in soybean and soil samples with a quantitative, real-time PCR assay. Plant Dis 91:736-742. https://doi.org/10. 1094/PDIS-91-6-0736

Martens-Habbena W, Berube PM, Urakawa H, de la Torre J, Stahl DA (2009) Ammonia oxidation kinetics determine niche separation of nitrifying Archaea and Bacteria. Nature 461:976-979. https://doi. org/10.1038/nature08465

Mosier A, Kroeze C, Nevison C, Oenema O, Seitzinger S, van Cleemput $\mathrm{O}$ (1998) Closing the global $\mathrm{N}_{2} \mathrm{O}$ budget : nitrous oxide emissions through the agricultural nitrogen cycle inventory methodology. Nutr Cycl Agroecosystems 52:225-248. https://doi.org/10.1023/A: 1009740530221

Nakanishi Y, Zhou S, Kim SW, Fushinobu S, Maruyama J, Kitamoto K, Wakagi T, Shoun H (2010) A eukaryotic copper-containing nitrite reductase derived from a NirK homolog gene of Aspergillus oryzae. Biosci Biotechnol Biochem 74:984-991. https://doi.org/10.1271/ bbb. 90844

Nicol GW, Leininger S, Schleper C, Prosser JI (2008) The influence of soil $\mathrm{pH}$ on the diversity, abundance and transcriptional activity of ammonia oxidizing archaea and bacteria. Environ Microbiol 10: 2966-2978. https://doi.org/10.1111/j.1462-2920.2008.01701.x

Nugroho RA, Röling WFM, Laverman AM, Verhoef HA (2006) Net nitrification rate and presence of Nitrosospira cluster 2 in acid coniferous forest soils appear to be tree species specific. Soil Biol Biochem 38:1166-1171. https://doi.org/10.1016/j.soilbio.2005.09. 011

Owens J, Clough TJ, Laubach J, Hunt JE, Venterea RT, Phillips RL (2016) Nitrous oxide fluxes, soil oxygen, and denitrification potential of urine- and non-urine-treated soil under different irrigation frequencies. J Environ Qual 45:1169-1177. https://doi.org/10. 2134/jeq2015.10.0516

Pereira EIP, Suddick EC, Mansour I, Mukome FND, Parikh SJ, Scow K, Six J (2015) Biochar alters nitrogen transformations but has minimal effects on nitrous oxide emissions in an organically managed lettuce mesocosm. Biol Fertil Soils 51:573-582. https://doi.org/10.1007/ s00374-015-1004-5

Qin S, Ding K, Clough TJ, Hu C, Luo J (2017) Temporal in situ dynamics of $\mathrm{N}_{2} \mathrm{O}$ reductase activity as affected by nitrogen fertilization and implications for the $\mathrm{N}_{2} \mathrm{O} /\left(\mathrm{N}_{2} \mathrm{O}+\mathrm{N}_{2}\right)$ product ratio and $\mathrm{N}_{2} \mathrm{O}$ mitigation. Biol Fertil Soils 53:723-727. https://doi.org/10.1007/s00374017-1232-y

Ravishankara AR, Daniel JS, Portmann RW (2009) Nitrous oxide $\left(\mathrm{N}_{2} \mathrm{O}\right)$ : the dominant ozone-depleting substance emitted in the 21 st century. Science 326:123-125. https://doi.org/10.1126/science.1176985

Reed DW, Smith JM, Francis CA, Fujita Y (2010) Responses of ammonia-oxidizing bacterial and archaeal populations to organic nitrogen amendments in low-nutrient groundwater. Appl Environ Microbiol 76:2517-2523. https://doi.org/10.1128/AEM.02436-09

Rees E, Siddiqui RA, Köster F, Schneider B, Friedrich B (1997) Structural gene (nirS) for the cytochrome cd1 nitrite reductase of Alcaligenes eutrophus H16. Appl Environ Microb 63:800-802

Rubin BE, Gibbons SM, Kennedy S, Hampton-Marcell J, Owens S, Gilbert JA (2013) Investigating the impact of storage conditions on microbial community composition in soil samples. PLoS One 8:e70460

Schöler A, Jacquiod S, Vestergaard G, Schulz S, Schloter M (2017) Analysis of soil microbial communities based on amplicon sequencing of marker genes. Biol Fertil Soils 53:485-489. https://doi.org/ 10.1007/s00374-017-1205-1

Shan J, Yang P, Shang X, Rahman MM, Yan X (2018) Anaerobic ammonium oxidation and denitrification in a paddy soil as affected by temperature, $\mathrm{pH}$, organic carbon, and substrates. Biol Fertil Soils 54: 341-348. https://doi.org/10.1007/s00374-018-1263-Z

Shen XY, Zhang LM, Shen JP, Li LH, Yuan CL, He JZ (2011) Nitrogen loading levels affect abundance and composition of soil ammonia oxidizing prokaryotes in semiarid temperate grassland. J Soils Sediments 11:1243-1252. https://doi.org/10.1007/s11368-011-0375-y

Shoun H, Kim DH, Uchiyama H, Sugiyama J (1992) Denitrification by fungi. FEMS Microbiol Lett 94:277-281. https://doi.org/10.1016/ 0378-1097(92)90643-3

Siddique AB, Unterseher M (2016) A cost-effective and efficient strategy for Illumina sequencing of fungal communities: a case study of beech endophytes identified elevation as main explanatory factor for diversity and community composition. Fungal Ecol 20:175185. https://doi.org/10.1016/j.funeco.2015.12.009

Stempfhuber B, Richter-HeitmannLisa T, Bienek L, Schöning I, Schrumpf M, Friedrich M, Schulz S, Schloter M (2017) Soil pH and plant diversity drive co-occurrence patterns of ammonia and nitrite oxidizer in soils from forest ecosystems. Biol Fertil Soils 53:691-700. https://doi.org/10.1007/s00374-017-1215-Z

Stenberg B, Johansson M, Pell M, Sjödahl-Svensson K, Stenström J, Torstensson L (1998) Microbial biomass and activities in soil as affected by frozen and cold storage. Soil Biol Biochem 30:393-402

ter Braak CJF (1989) CANOCO-an extension of DECORANA to analyze species-environment relationships. Hydrobiologia 184:169 170

Vestergaard G, Schulz S, Schöler A, Schloter M (2017) Making big data smart-how to use metagenomics to understand soil quality. Biol Fertil Soils 53:479-484. https://doi.org/10.1007/s00374-017-1191-3

Wang Q, Wang J, Li Y, Chen D, Ao J, Zhou W, Shen D, Li Q, Huang Z, Jiang Y (2018) Influence of nitrogen and phosphorus additions on $\mathrm{N}_{2}$-fixation activity, abundance, and composition of diazotrophic communities in a Chinese fir plantation. Sci Total Environ 619620:1530-1537. https://doi.org/10.1016/j.scitotenv.2017.10.064

Wei W, Isobe K, Shiratori Y, Nishizawa T, Ohte N, Otsuka S, Senoo K (2014) $\mathrm{N}_{2} \mathrm{O}$ emission from cropland field soil through fungal denitrification after surface applications of organic fertilizer. Soil Biol Biochem 69:157-167. https://doi.org/10.1016/j.soilbio.2013.10.044

Wei W, Isobe K, Shiratori Y, Nishizawa T, Ohte N, Ise Y, Otsuka S, Senoo K (2015) Development of PCR primers targeting fungal nirK to study fungal denitrification in the environment. Soil Biol Biochem 81:282-286. https://doi.org/10.1016/j.soilbio.2014.11.026

Weier KL, Doran JW, Power JF, Walters DT (1993) Denitrification and the dinitrogen nitrous-oxide ratio as affected by soil-water, available carbon, and nitrate. Soil Sci Soc Am J 57:66-72. https://doi.org/10. 2136/sssaj 1993.03615995005700010013x

Weiss S, Xu ZZ, Peddada S, Amir A, Bittinger K, Gonzalez A, Lozupone C, Zaneveld JR, Vázquez-Baeza Y, Birmingham A, Hyde ER, Knight R (2017) Normalization and microbial differential abundance strategies depend upon data characteristics. Microbiome 5: 27. https://doi.org/10.1186/s40168-017-0237-y 
Wertz S, Goyer C, Zebarth BJ, Burton DL, Tatti E, Chantigny MH, Filion $\mathrm{M}$ (2013) Effects of temperatures near the freezing point on $\mathrm{N}_{2} \mathrm{O}$ emissions, denitrification and on the abundance and structure of nitrifying and denitrifying soil communities. FEMS Microbiol Ecol 83: 242-254. https://doi.org/10.1111/j.1574-6941.2012.01468.x

Xu N, Tan G, Wang H, Gai X (2016) Effect of biochar additions to soil on nitrogen leaching, microbial biomass and bacterial community structure. Eur J Soil Biol 74:1-8. https://doi.org/10.1016/j.ejsobi. 2016.02.004

Yang Y, Meng T, Qian X, Zhang J, Cai Z (2017) Evidence for nitrification ability controlling nitrogen use efficiency and $\mathrm{N}$ losses via denitrification in paddy soils. Biol Fertil Soils 53:349-356. https://doi.org/ 10.1007/s00374-017-1185-1

Yang YD, Hu YG, Wang ZM, Zeng ZH (2018) Variations of the nirS-, nirK-, and nosZ-denitrifying bacterial communities in a northern Chinese soil as affected by different long-term irrigation regimes. Environ Sci Pollut Res 25:14057-14067. https://doi.org/10.1007/ s11356-018-1548-7

Yin C, Fan F, Song A, Cui P, Li T, Liang Y (2015) Denitrification potential under different fertilization regimes is closely coupled with changes in the denitrifying community in a black soil. Appl Microbiol Biotechnol 99:5719-5729. https://doi.org/10.1007/ s00253-015-6461-0
Zehr JP, Kudela RM (2011) Nitrogen cycle of the open ocean: from genes to ecosystems. Annu Rev Mar Sci 3:197-225

Zhang J, Zhou X, Chen L, Chen Z, Chu J, Li Y (2016) Comparison of the abundance and community structure of ammonia oxidizing prokaryotes in rice rhizosphere under three different irrigation cultivation modes. World J Microbiol Biotechnol 32:85. https://doi.org/10. 1007/s11274-016-2042-3

Zhou ZF, Zheng YM, Shen JP, Zhang LM, He JZ (2011) Response of denitrification genes nirS, nirK, and nosZ to irrigation water quality in a Chinese agricultural soil. Environ Sci Pollut Res 18:1644-1652. https://doi.org/10.1007/s11356-011-0482-8

Zhu YG, Johnson TA, Su JQ, Qiao M, Guo GX, Stedtfeld RD, Hashsham SA, Tiedje JM (2013) Diverse and abundant antibiotic resistance genes in Chinese swine farms. Proc Natl Acad Sci U S A 110: 3435-3440. https://doi.org/10.1073/pnas.1222743110

Zumft WG (1997) Cell biology and molecular basis of denitrification. Microbiol Mol Biol R 61:533-616

Publisher's note Springer Nature remains neutral with regard to jurisdictional claims in published maps and institutional affiliations. 